\title{
Recent Developments in Solar Thermal Desalination Technologies: A Review
}

\author{
Ihsan Ullah and Mohammad G. Rasul * \\ School of Engineering and Technology, Central Queensland University, Rockhampton, Queensland 4702, \\ Australia; ihsan.ullah@cqumail.com \\ * Correspondence: m.rasul@cqu.edu.au; Tel.: +61-402-431-669
}

Received: 5 September 2018; Accepted: 21 December 2018; Published: 30 December 2018

\begin{abstract}
Fresh water resources are depleting rapidly as the water demand around the world continues to increase. Fresh water resources are also not equally distributed geographically worldwide. The best way to tackle this situation is to use solar energy for desalination to not only cater for the water needs of humanity, but also to offset some detrimental environmental effects of desalination. A comprehensive review of the latest literature on various desalination technologies utilizing solar energy is presented here. This paper also highlights the environmental impacts of desalination technologies along with an economic analysis and cost comparison of conventional desalination methods with different solar energy based technologies. This review is part of an investigation into integration of solar thermal desalination into existing grid infrastructure in the Australian context.
\end{abstract}

Keywords: solar desalination; fresh water; desalination technologies; environmental impacts; cost of solar desalination

\section{Introduction}

Fresh water sources are depleting rapidly as the global demand for water continues to increase because of rising demands for natural resources combined with the effects of climate change, especially in dry land and coastal/inland regions. Water and energy are vital commodities for living beings on this planet. The water and energy resources have helped them achieve prosperity and development in various parts of the developed world, while many regions in the developing countries suffer from severe fresh water and energy shortages [1]. The United Nations Environmental Programme (UNEP) mentioned in one of their findings in 2012 that one third of the world's population have access to fresh water resources for their livelihood, while the rest will suffer acute water shortage by year 2025 [2]. Drinking water of acceptable quality has become a rare consumption product. According to the World Health Organization (WHO) and United Nations International Children's Emergency Fund (UNICEF) Joint Monitoring Programme for Water Supply and Sanitation, more than 1.8 billion people around the world will have access to polluted drinking water [3]. There is still a large portion of the population around the world with no access to drinking water and the delivery itself is through unsafe sanitary systems. Unfortunately, in addition to being in shortage, fresh water resources are also not equally distributed geographically worldwide [4]. The best way to grapple with this situation for humanity is to find some alternative means of fresh water production. Fortunately, desalination technology has the capability to tackle this issue, however, it is very energy intensive and it has drastic effects on the environment [5]. A quick overview of various types of raw feed water is as follows.

Fresh water contains less than $1 \%$ sodium chloride $(\mathrm{NaCl})$, brackish water contains less than $3 \%$ sodium chloride, and seawater usually contains around 3.5\% sodium chloride. Seawater is more corrosive compared to fresh water due to the penetrating power of the chloride ion through surfaces 
films on a metal and higher conductivity. Waste water is the discarded water after use like private sanitary waste or industrial waste, and is contaminated with soaps, fecal matter and detergents etc. Grey water is the waste water from showers, spas, baths, laundry tubs, washing machines and handbasins, while water from toilets is called black water. There are different desalination processes employed worldwide to remove salts from seawater $(67 \%)$, brackish water $(19 \%)$, river water $(8 \%)$ and wastewater $(6 \%)[6,7]$.

Desalination of seawater has remained one of oldest water treatment processes in human history, and it has proven to be one of the most reliable backup choices for addressing fresh water needs of not only human beings but industries as well. Desalination has been instrumental in the socio-economic uplift of people in different developing countries around the world [8], mostly in the water deficient areas like Africa, Asia Pacific and Middle East countries [9]. Population growth, along with the development in the industrial and agriculture sector in emerging economies, will swiftly deteriorate and deplete the available fresh water resources. Desalination of seawater and brackish water has the capacity to address the increasing fresh water needs of humanity. Yet, it is not sustainable because it consumes a lot of energy, mainly from fossil fuels which can be hard to supply to remote areas and the prices of which are highly volatile. Some countries in the Middle East like Qatar and Kuwait are totally reliant on desalinated water for household and commercial supplies [10]. Global water withdrawals are more than 4000 billion $\mathrm{m}^{3}$ annually [11] and about one fourth of the world population faces fresh water shortages [9,12]. Australia is the driest continent on Earth, and its Bureau of Meteorology predicts the immediate impact of climate change will be less rainfall in the highly populated areas in the southeast and southwest of the country [13]. The severe Millennium Drought [14] and climate change have impelled some of Australia's major cities to build 6 large-scale desalination plants with a cumulative capacity of almost $1.5 \mathrm{GL} /$ day in five different states to cater for the fresh water needs irrespective of rainfall [15].

Desalination treats water by dissociating salts from saline water, resulting in potable water which has low levels of dissolved organic and inorganic salts called total dissolved solids (TDS). There were about 18,436 desalination plants worldwide as of June 30, 2015 according to the International Desalination Association (IDA) [16]. These have a commissioned capacity of 92.5 million $\mathrm{m}^{3} /$ day catering for the water needs of over 300 million people globally who fully/partially rely on desalinated water for their daily water consumption, and the cumulative contracted capacity is estimated at $99.8 \mathrm{~m}^{3}$ /day worldwide $[17,18]$.

The desalination plants with high production capacities are mostly installed in the Middle East. Seawater desalination in the Persian Gulf, Gulf of Oman, and Red Sea which have an acute shortage of potable water resources, represents $65 \%$ of global water desalination capacity $[19,20]$. The worldwide distribution of desalination capacities (million $\mathrm{m}^{3}$ /day) in 2009 is shown in Figure 1 [21]. The MENA (Middle East and North Africa) region currently has 2800 desalination plants producing 37.32 million $\mathrm{m}^{3} /$ day of potable water which is approximately $44 \%$ of the global capacity $[19,22]$. Desalination technology processes are either thermal processes utilizing both electricity and heat [23], or membrane technologies which are only electricity based [24]. As per the International Desalination Association's current statistics, reverse osmosis (RO), a membrane process, comprizes nearly $65 \%$ of installed capacity, thermal multi-stage flash (MSF) processes make up 21\%, multi-effect distillation (MED) provides $7 \%$, electro-dialysis and electro dialysis/reversal/(ED/EDR) provide 3\%, nano-filtration provides $2 \%$, and others contribute $2 \%$ as illustrated in Figure $2[24,25]$. 


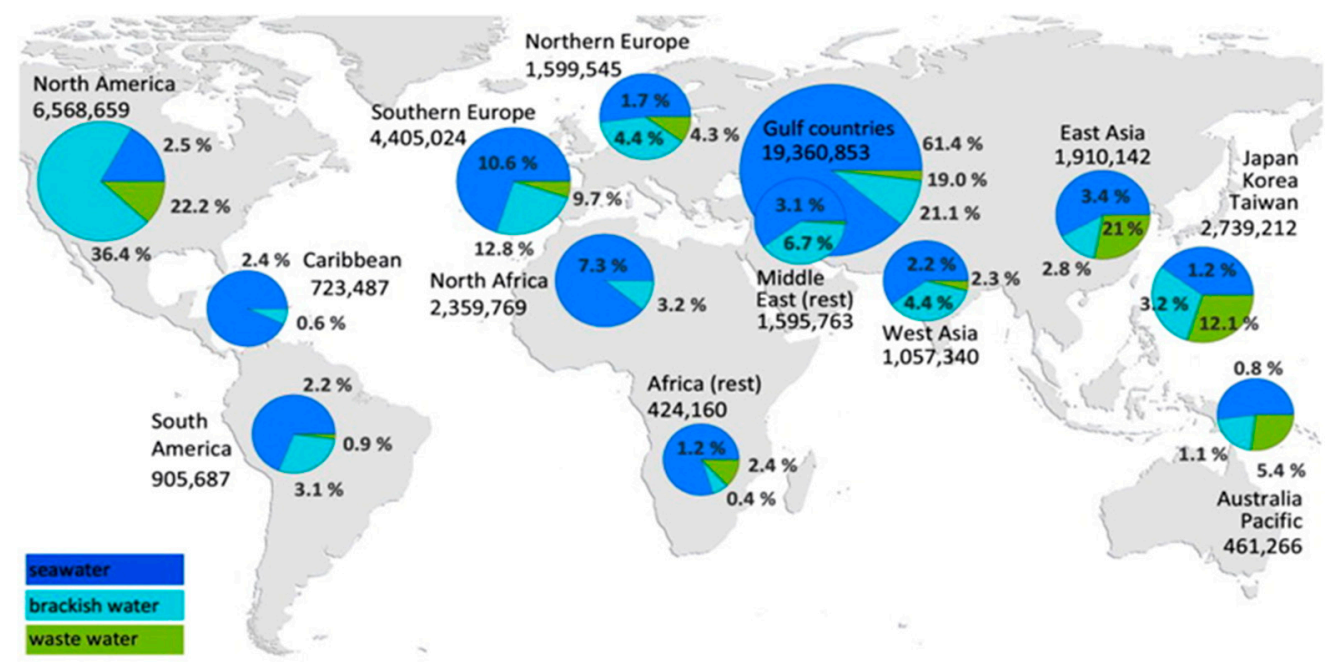

Figure 1. Global distribution of desalination capacities (million $\mathrm{m}^{3} /$ day) as of 2013 [21].

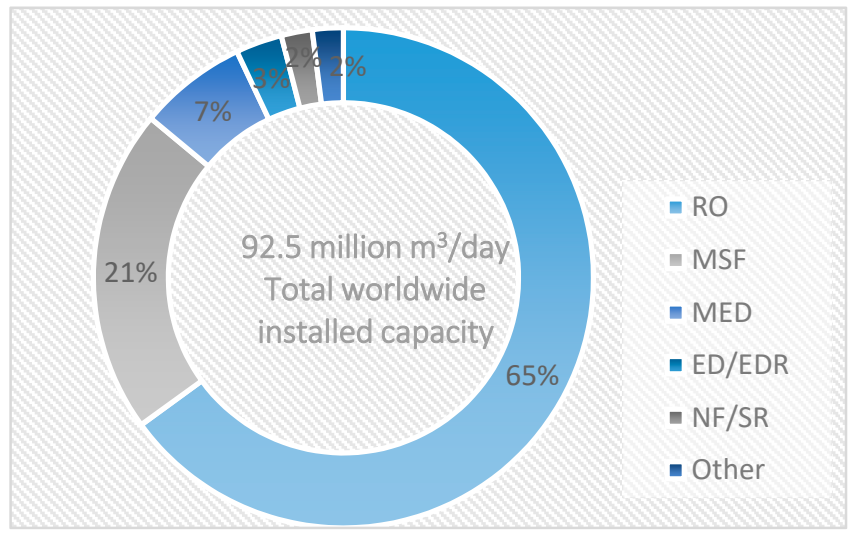

Figure 2. Total global installed capacity by technology type re-drawn from [26].

The exponential increment in demand for potable water has seen a massive investment in desalination technologies globally and the international desalination market is currently growing at a very rapid rate of $55 \%$ per annum to meet the demand [24,27]. In addition, we can see from Figure 3 on the left side that power, refining, oil and gas continue as the leading industries using desalination in 2015; however, mining, food and beverage, and electronics indicate growth compared to historical distribution as per the 28th Worldwide Desalting Plant Inventory as shown on the right side of Figure 3.

This paper gives an insight into the current desalination status globally and then further explores different opportunities for undertaking solar water desalination technologies to tackle the severe water shortage issue the world is currently facing. It also gives a thorough insight into the latest published works on several solar based desalination technologies. This paper will also highlight in detail the environmental impacts of desalination technologies along with an economic analysis and cost comparison of conventional desalination methods with different solar energy based technologies. 


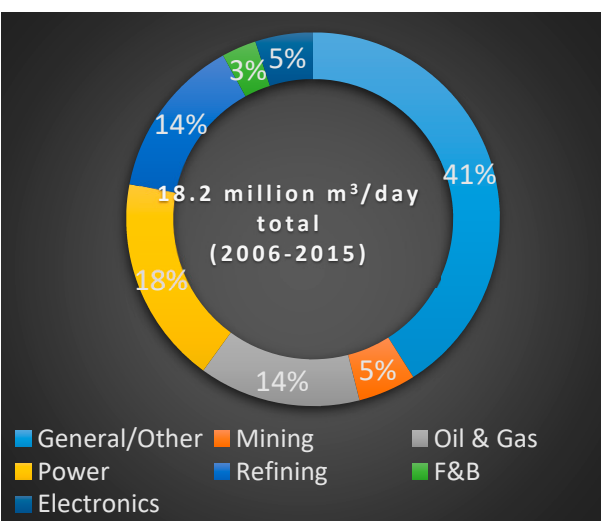

(a)

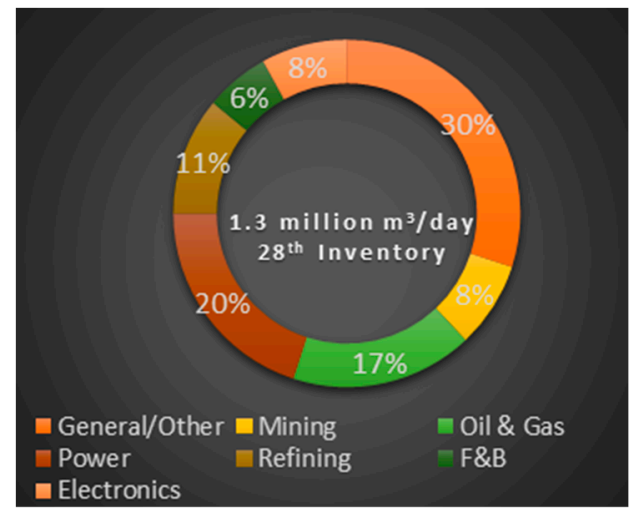

(b)

Figure 3. Total worldwide installed capacity by user type re-drawn from [26]. (a) Leading industries use desalination; (b) 28th Worldwide desalting plant inventory.

\section{Energy and Water Desalination: A Complex Nexus}

The energy and water dependency portrays a pivotal connection globally between the water and energy issues. But, while realization of this compelling water-energy nexus is felt and understood around the world, policies influencing both energy and water remain ill-considered at best and alarmingly disadvantageous at worst. There is a substantial energy footprint associated with supply, treatment and distribution of water. Conversely, energy production requires a substantial water consumption, resulting in an increased international limelight on the water-energy nexus, which is a term used for the correlation between these two vital utilities. This correlation between energy and water resources is shown in Figure 4 [28].

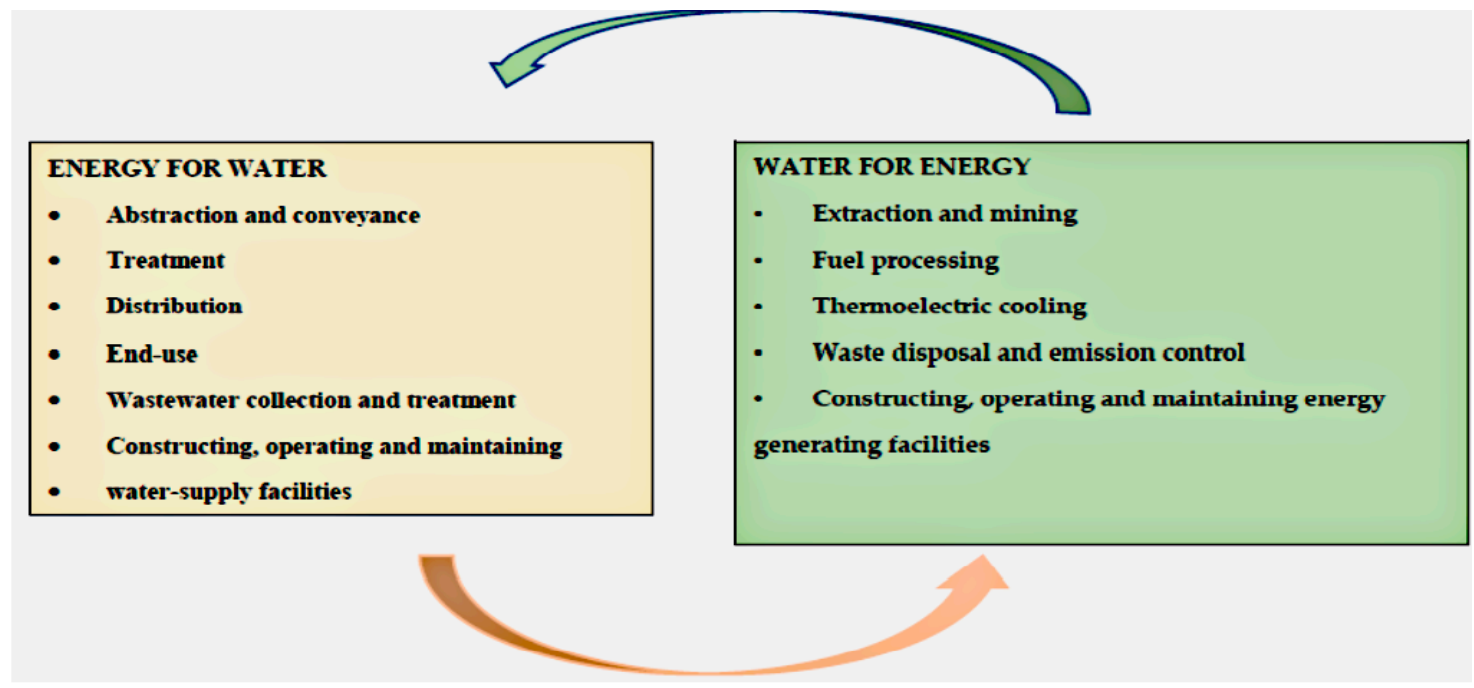

Figure 4. Illustration of the water-energy nexus adapted from [28].

Water, energy and desalination have a very close interconnection which grows further as growing population and varying consumption patterns increase the demand for water resources [25]. Currently, most of the desalination plants are situated in areas where traditional energy is readily available and at low cost [29]. Unfortunately, as per the International Renewable Enery Agency (IRENA) 2012 technology statistics, only $1 \%$ of total desalinated water is renewable energy based [30]. Renewable energy sources are consistently becoming more reliable and common as the costs associated with renewable technology decrease every year, thus resulting in a widespread use of renewable energy in many parts of the world [9,31]. The global capacity of desalination plants, including renewable desalination, grew more than $9 \%$ annually between 2010 and 2016, with a total expenditure of around 
US $\$ 88$ billion [32]. Figure 5 shows the promising prospects of the desalination market in both developed and emerging countries such as the United States, China, Saudi Arabia (SA) and the United Arab Emirates (UAE) [1]. There is a substantial capacity in rural and remote areas and the rest of the world (ROW), and islands too, where grid electricity or fossil fuels may not be the best option to generate energy at economical cost. It is expected that approximately $54 \%$ of the global growth in desalination will occur in the MENA region [30].

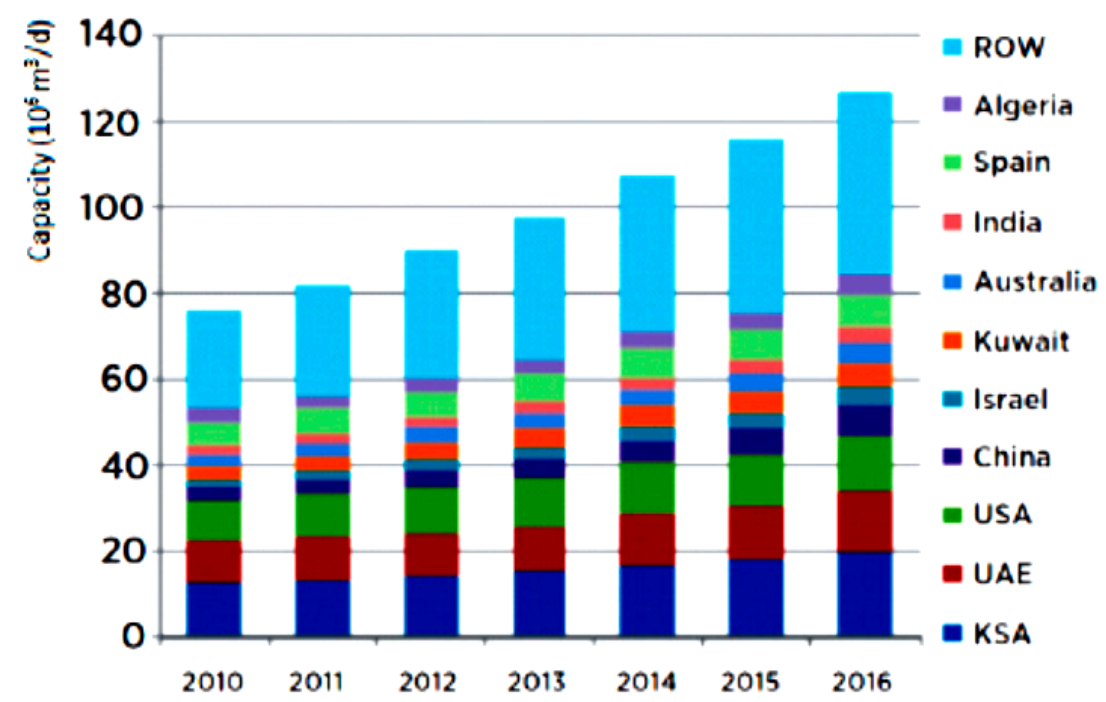

Figure 5. Global installed desalination capacity, year 2010-2016 [32].

The world's water per capita consumption is increasing twofold every two decades, and shall exceed population growth by two fold [33]. Accordingly, water scarcity will impact one-third of the population around the world $[29,34]$. Similarly, it is projected that, by 2040, global energy demand will increase by more than a quarter of the current demand, resulting in rise of the cost for water utilization by the energy sector [35]. Water and energy management will become even more difficult and complicated through further water discrepancies and severe weather events, resulting in severe floods and drought due to climate change. Approximately one fifth of the world's population live in water scarce areas. The demand for water is approaching unsustainable levels. It is envisioned that, by 2025 , the demand for water will increase by $55 \%$ [36]. To keep pace with this demand, we should develop continuous and viable water supplies, safeguard fresh water resources, enhance efficiency and minimize our environmental footprint, using desalination as a tool [37]. By 2025, approximately two-thirds of the global population will have no access to clean water [38]. Desalination has the potential to close the gap on water scarcity. The discrepancy between fresh water requirements and its availability will further worsen as competing needs for water intensify along with urbanization, population growth, the climate change impacts on the environment and increases in demand for domestic and industrial water [39].

The facts are that the abundant renewable energy resources are still largely untapped around the world and the dependence on fossil fuels will continue as it is still envisaged to be an extremely profitable and credible form of energy. Nevertheless, large-scale deployment of desalination has encountered a few challenges, which has resulted in high energy demand and $\mathrm{CO}_{2}$ emissions from hydrocarbon energy sources [40]. There are remarkable prospects of developing integrated desalination and renewable energy technologies as a medium and long-term approach, by promoting technically viable renewable energy systems with funding and investment [9,34]. Whether these sustainable desalination systems could be technically viable for catering for water needs remains to be ascertained. There are different approaches used to develop viable alternatives that could be accomplished through the adoption of an integrated water management strategy which is based on renewable energy sources for water treatment technologies. For example, in Australia, such a strategy endeavors to attain 
sustainable usage of the nation's water resources by safeguarding and intensifying their quality without compromising financial and public development [41,42]. These viable alternatives include water desalination, wastewater reuse and rainwater harvesting systems. The adoption of these approaches in desalination technologies has resulted in affordable water supply and greater energy efficiency [43,44]. The unit cost of the amount of energy required to produce $1 \mathrm{~m}^{3}$ of fresh water has significantly decreased in recent years, meaning that there will be significant reductions in the number of PV modules and also in the required solar collector areas in solar based desalination technologies [45]. These technological breakthroughs would result in ample fresh water both from seawater and brackish water with minimum consequences on the environment when connected with renewables and solar energy solely. As the majority of the MENA region, the Arabian Gulf area, China, India, and countries in Africa lie on the Sunbelt, the Gulf Cooperation Countries (GCC) are therefore striving hard to produce water by constructing new desalination plants to ease water shortages and deal with the real threat to resource sustainability [46]. For example, Saudi Arabia and the United Arab Emirates are working hard towards managing the available water reservoirs to satisfy water demand growth to prevent brisk degradation and exhaustion of its brackish water levels [9,47]. Consequently, Saudi Arabia anticipates solar energy to be the best alternative to fulfilling the growing demand of water and energy in the long term. The Al Khafji desalination plant in Al Khafji City is the world's first large-scale solar-powered desalination plant in Saudi Arabia. Advanced Water Technology (AWT) and Abengoa joint venture were awarded the contract to build this solar-powered desalination plant at an estimated cost of US $\$ 130 \mathrm{~m}$. This plant delivers $60,000 \mathrm{~m}^{3}$ of desalinated seawater per day, ensuring a regular supply of water to the surrounding province the whole year round [48].

\section{Solar Desalination Technologies}

The majority of the desalination systems either require thermal or electrical energy input that is harnessed from solar energy and, therefore, there has been a lot of emphasis on solar-based systems (photovoltaic (PV) systems and concentrated solar thermal collectors) recently due to depleting fossil fuels and their detrimental effects on the environment. In a solar PV system, the solar cells absorb the incident solar radiation and convert it to electricity. PV collectors have efficiencies between 8 and 12\%. Major types of PV panels are crystalline silicon, thin films, and semiconductor thin films [49-51], while concentrating solar thermal collectors collect heat by absorbing sunlight. There are different types of solar thermal collectors, e.g., flat plate collectors, evacuated tube collectors, and parabolic trough collectors, etc., and these collectors have efficiencies much higher than the PV systems. A comparison of the performance and price range of different PV technologies is shown in Figure 6 [52].

Desalination is classified as follows:

(a) Thermal or distillation processes that heat the saltwater to boiling, collect and condense the steam producing purified water; variations are multi-stage flash (MSF), multi-effect distillation (MED), membrane distillation, and vapor compression distillation (VCD) [53];

(b) Membrane technology processes of reverse osmosis (RO), electro-dialysis and electro-dialysis reversal (ED/EDR) methods involving forcing saltwater across a semipermeable membrane that removes the salts from the water, leaving brine on one side and drinkable water on the other [33]; and

(c) Alternative processes consisting of freezing and ion exchange [54].

The detailed classification of solar desalination systems can be found in [5]. One such example is given in Figure 7. 


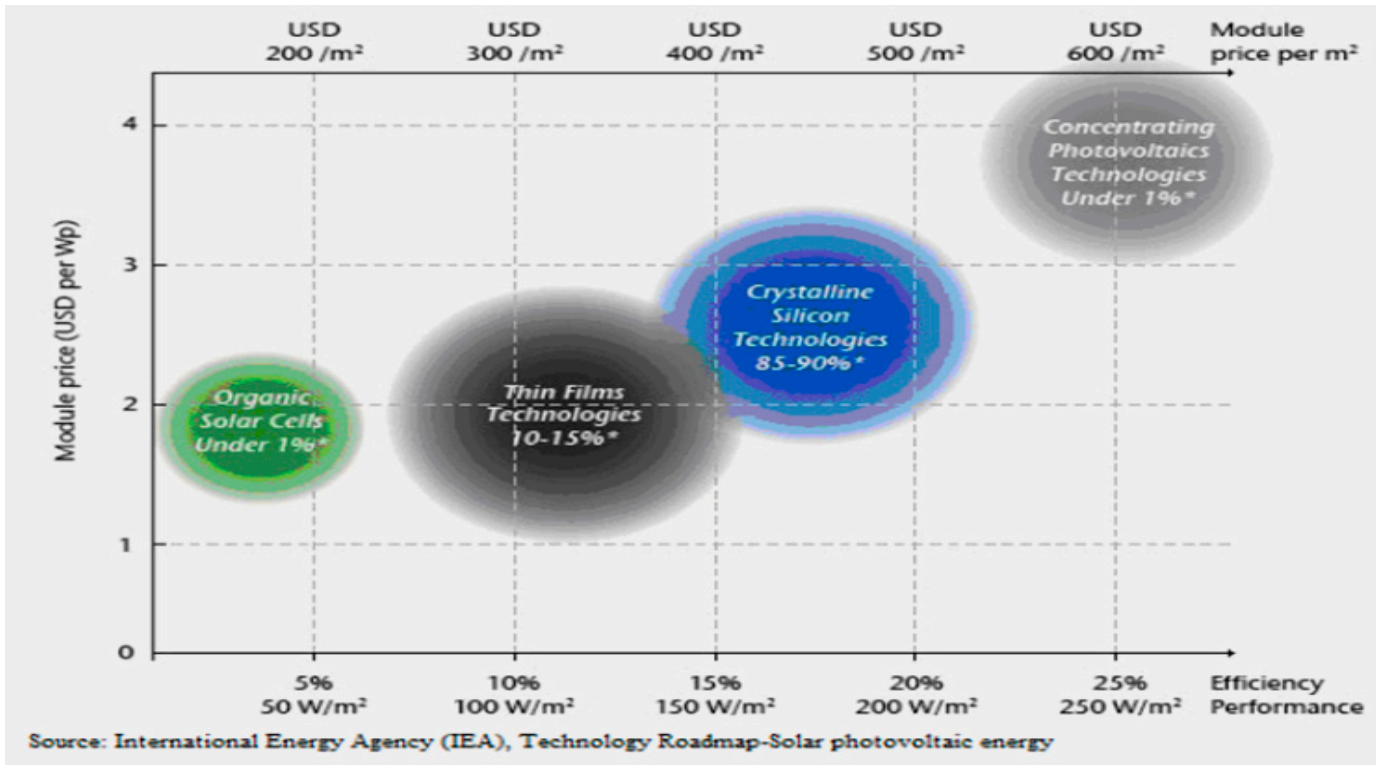

Figure 6. Comparison of performance and price range of PV technologies [52].

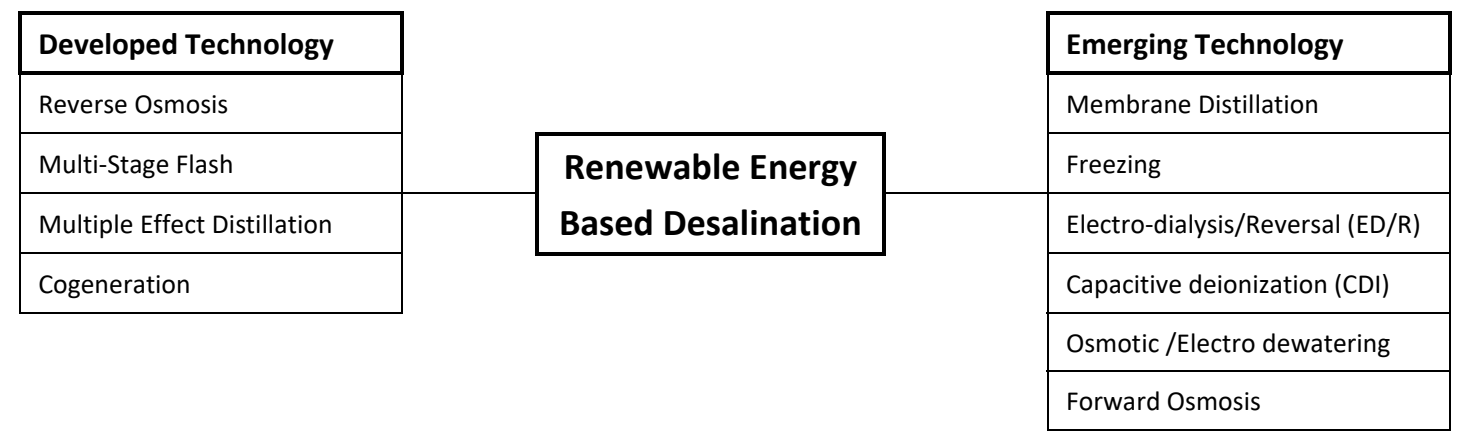

Figure 7. Classification of Solar-based Desalination systems (adapted from [5]).

Saudi Arabia, Kuwait, USA and UAE have the highest desalination capacities around the world. The three Gulf Cooperation Council countries, i.e., Saudi Arabia, UAE and Kuwait alone are responsible for more than one-third of the global desalination capacity. The MSF, RO and MED processes are at more mature and developed stages to be integrated with solar energy to cater for the potable water needs of the GCC countries like Saudi Arabia, UAE, Qatar, Kuwait, Bahrain and Oman, where two-thirds of their water needs are met with these technologies. The unit cost has been reduced due to integration with solar energy such as in the case of MED coupled with solar powered adsorption cycles which resulted in $\$ 0.5 / \mathrm{m}^{3}$ in the Yanbu desalination plant [55]. The financial cost and harmful $\mathrm{CO}_{2}$ emissions can be significantly reduced with integration of $\mathrm{PV}$ with these technologies. On the other hand, emerging technologies such as MD, ED/R, FO, etc., have been primarily used for small scale production of fresh water in remote areas where water and electricity supply is not economically feasible. However, higher production cost, and integration with PV/solar thermal being limited by economical and technical barriers are hindrances in the large scale adoption of these technologies at this stage [53].

\subsection{Thermal Processes}

\subsubsection{Solar Powered Multi-Stage Flash Distillation (MSF)}

Solar powered MSF is a type of thermal desalination which involves using a solar source to heat saltwater under high pressures and it is then passed through a series of chambers. The saltwater passes through several successive chambers each with a lower pressure than the preceding one, thus 
resulting in even more vaporization of saltwater. The evaporated water is collected and re-condensed into refined water. The water that did not vaporize exits the system with a higher saline concentration than when it entered; this is discarded appropriately as waste while the refined water is discharged into the municipal water supply as potable water $[33,56,57]$. The solar based MSF process is shown in Figure 8 .

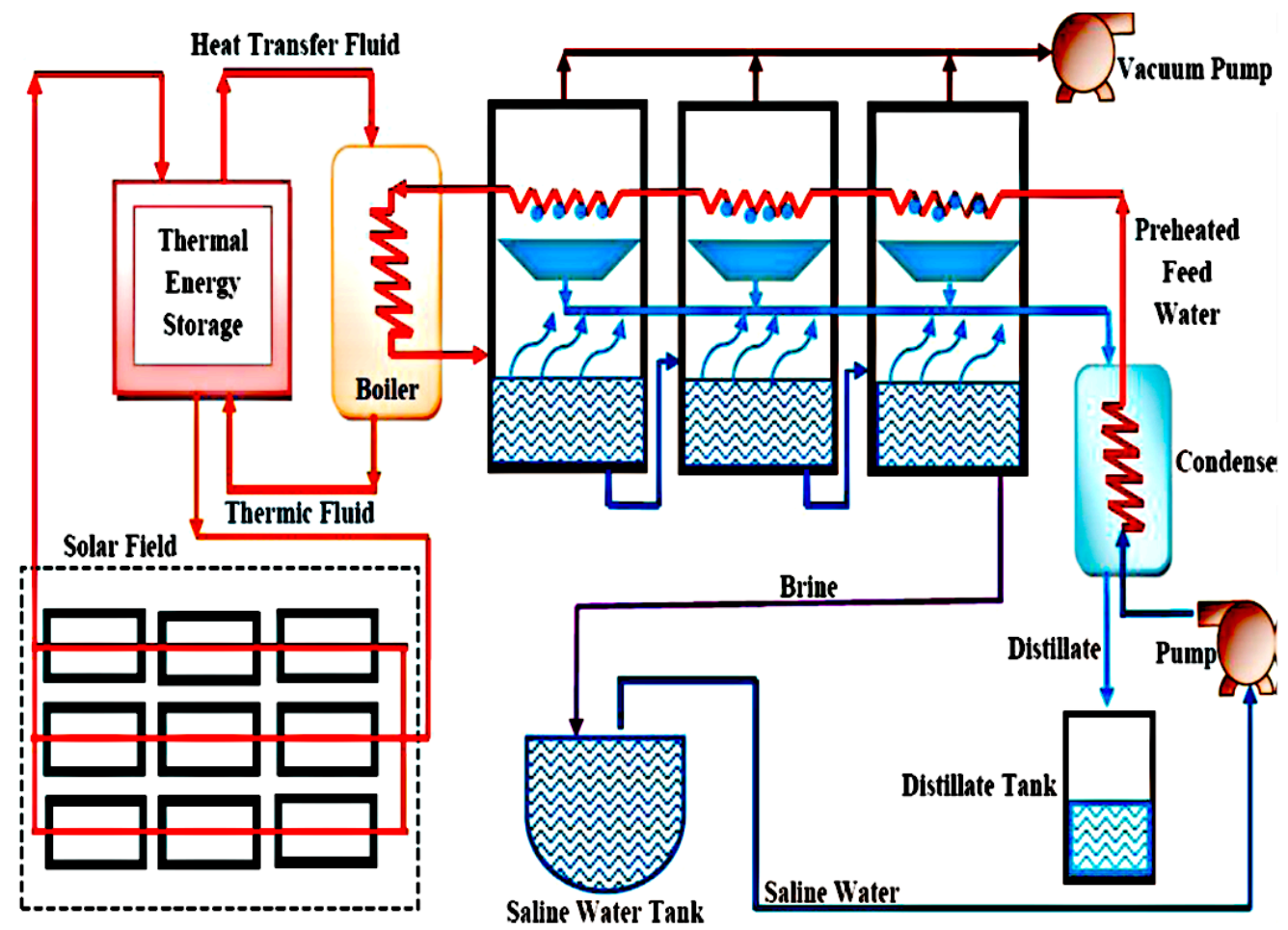

Figure 8. Solar powered multi-stage flash distillation [58].

MSF is a frequently used thermal technology in the Middle East utilizing fossil fuels [59]. The world's largest desalination plants operate on this technology with their specific energy consumption (SEC) in the range of $81-106 \mathrm{kWh} / \mathrm{m}^{3}$ for a temperature difference between inlet seawater and hot brine of $10-45^{\circ} \mathrm{C}$ [60]. The gain output ratio (GOR) is an estimate of how much thermal energy is used in a desalination process, i.e., how many kilograms of distilled water are produced per kilogram of steam consumed. GORs in the range of 6.5-8 are quite customary for a MSF plant with a recovery ratio (RR) of $6 \%[57,60]$. The capital cost components of a standalone solar powered MSF plant comprize solar collectors, battery storage, PV arrays, thermal storage or fossil fuel powered generator, desalination unit and steam generator. Operating costs consist of chemical cost, maintenance cost and personnel cost which are less than one fifth of total cost [61]. Cost of water obtained from solar-MSF plants is around US $\$ 1.4 / \mathrm{m}^{3}$ [62,63]. An economic comparison carried out by García-Rodríguez and Gómez-Camacho [64] between solar-MSF with fossil fuel backup and a fossil fuel driven MSF plant revealed that the major parameters influencing water cost are the performance ratio (PR) and the solar fraction of the plant comparable to the case in solar cooling as recorded by [65]. Solar fraction illustrates the energy requirements of the plant supplied by the collector field, while performance ratio (PR) is the amount in $\mathrm{kg}$ of distillate water produced to the amount in $\mathrm{kg}$ of steam used [66].

\subsubsection{Multi-Effect Distillation (MED)}

MED is a type of thermal desalination process, which includes heating saltwater under pressure, which is then made to flow through a series of chambers (or stages). The heat for causing evaporation in the first chamber is provided by solar energy or by combustion of fossil fuel and the vapors thus formed are used to heat the feed water in the subsequent chamber. A portion of the feed water 
vaporizes, leaving behind a slightly more saline solution than the original saltwater. However, in this process the water vapor from each chamber (at high pressure) is used to heat the water in the subsequent chamber at a lower pressure than the preceding chamber. Although, this sequence is replicated in all subsequent chambers to enhance the efficiency of the overall system, the basic process uses the heat of condensation to provide heat to the next batch of saltwater, resulting in the separation of condensed water vapor (distilled water) and the production of more water vapor as the stages progress $[33,67]$. The solar powered MED process is illustrated in Figure 9.

Besides the thermodynamic primacy of MED over the MSF process, there is a substantial increase in heat transfer area in MED, resulting in a very low temperature drop in the range of $1.5-2.5^{\circ} \mathrm{C}$ in each stage. This enables the inclusion of a higher number of stages (10-16) even with a maximum brine temperature of as low as $70^{\circ} \mathrm{C}$, and this therefore results in a very high gain ratio (product to steam flow rates), which leads to a clear cost reduction $[68,69]$. There are various ways of supplying the feed seawater to the evaporators, namely forward, backward, parallel, and mixed feed systems $[65,70]$. A solar collector multi-effect distillation (MED) plant with a 14 effect-MED unit with a capacity of $72 \mathrm{~m}^{3}$ /day was installed at the solar research centre Plataforma Solar de Almería (PSA-CIEMAT) [71].

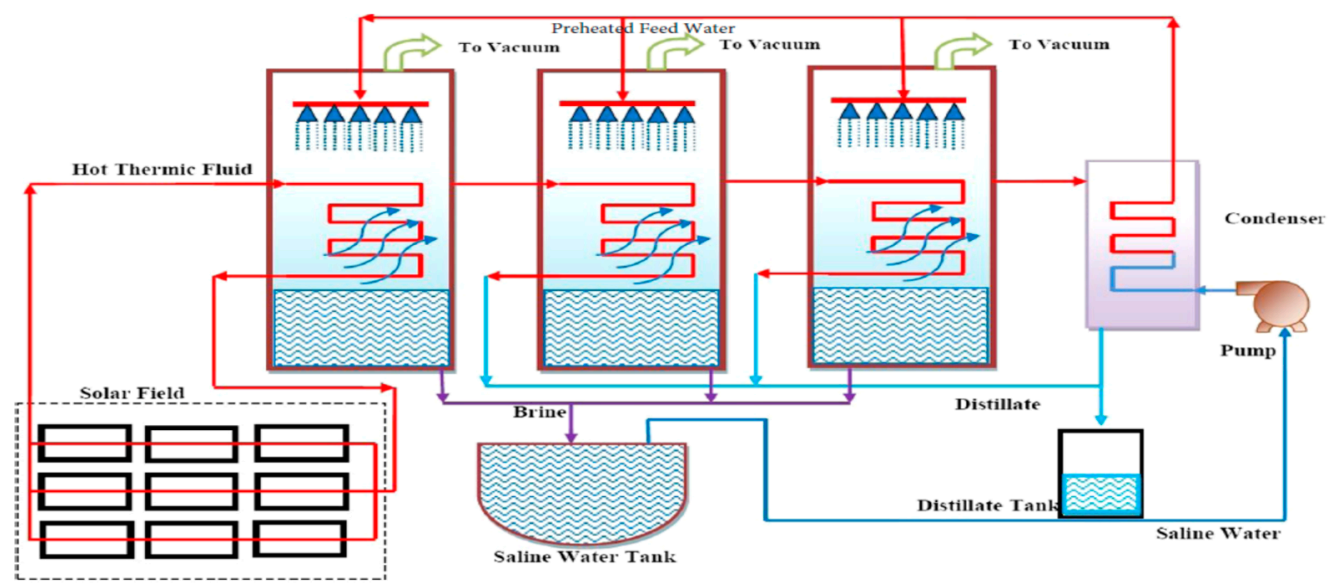

Figure 9. Solar powered Multi-Effect Distillation [72].

Pros/Cons of MED:

- The MED process operates at lower temperatures of approximately $70{ }^{\circ} \mathrm{C}$ which helps reduce tube corrosion and the likely scale formation around the tube surfaces [73];

- Low pre-treatment and operational costs because the quality of the feed water is not as essential as is the case in the RO process;

- $\quad$ The power consumption of MED is less than that of the MSF process [74];

- The MSF process is less proficient than the MED process in regards to heat transfer and fresh water production cost due to the fact that the performance efficiency in MSF plants is less than MED plants [75].

\subsubsection{Vapor Compression Distillation (VCD)}

VCD is the process in which the heat for vaporizing the seawater comes from vapor compression. Steam is generated from seawater through solar energy and allowed to flash, and the vapor is compressed using a mechanical vapor compressor or thermovapor compressor. Since increase in vapor pressure also produces an increase in the condensation temperature, the same vapor can suffice as the heating medium for its liquid or solution being concentrated, from which the vapor was originally generated. The incoming seawater causes the compressed steam to cool down, thus precipitating into distilled water and simultaneously heating the seawater to produce more steam [76,77] as illustrated in Figure 10. 
VCD is generally used in conjunction with multi-effect distillation for large-scale applications or standalone for small-scale applications. The crucial difference that provides VCD an edge is that the compression of vapor is used to alter the water boiling point [78]. It is used in places where fresh water is not easily available, like industries, resorts, and drilling sites. Pressure may reach up to $2000 \mathrm{kPa}$ depending upon the design of the plant $[79,80]$.

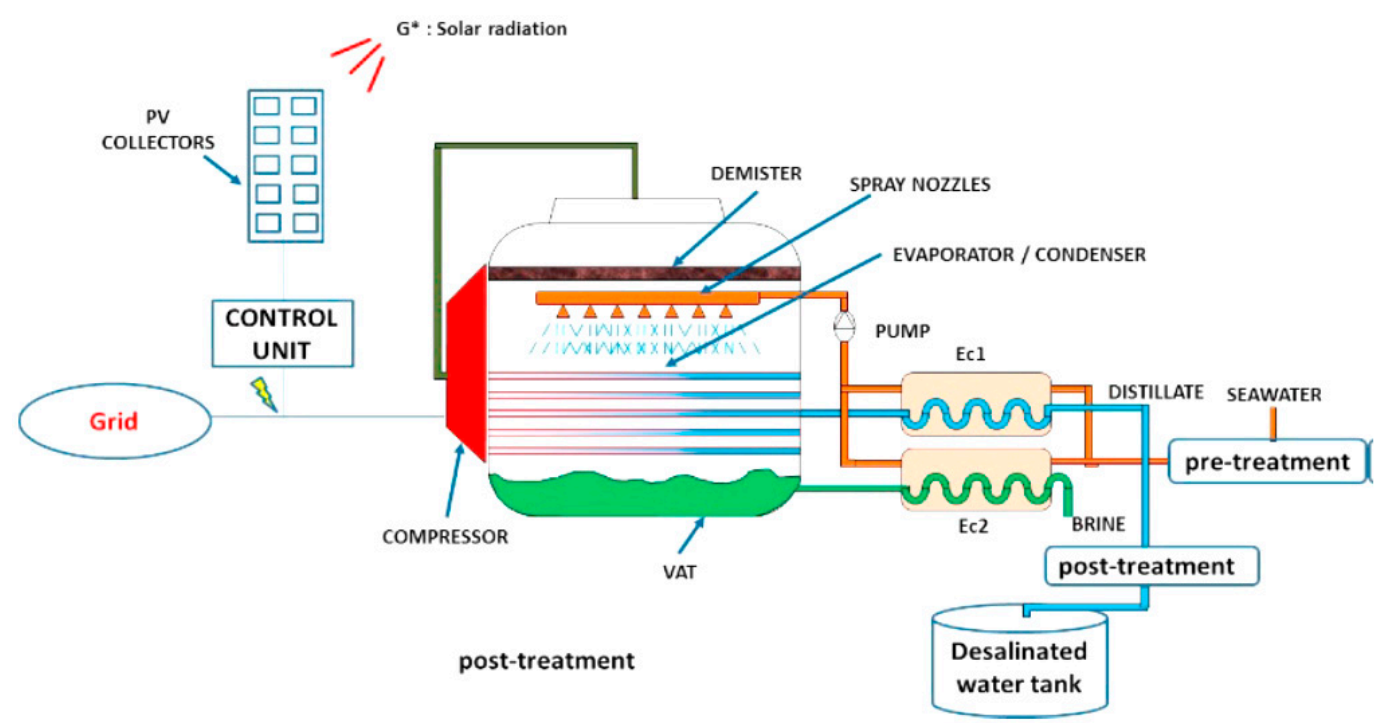

Figure 10. Vapor Compression Distillation system [81].

Pros:

- The equipment used for this process is smaller than MSF and MED;

- The operational expenditures are less in comparison with MSF and MED systems.

Cons:

- High energy consumption;

- Capital expenditures are high;

- Maintenance costs of compressors and heat exchangers are more when compared to other systems.

\subsection{Membrane Processes}

\subsubsection{Solar Powered Reverse Osmosis}

This is a process in which saltwater is made to pass under high pressures through a semipermeable membrane, producing nearly pure water on the downstream side and the salty water is left on the source side. As the efficiency of this process is dependent on the membrane cleanliness, the saltwater is therefore treated with some initial filters for separating particulate matter. Similarly, a post treatment often follows to not only get rid of any microbes in the water, but also to adjust the water's $\mathrm{pH}$ back to normal [33,82]. Solar powered RO units, either through flat plate collectors or concentrating solar collectors can be run with or without solar storage batteries as illustrated in Figure 11. A conventional large saline water RO plant constitutes five major components, namely a saline water supply system, a feed water pretreatment system, high-pressure pumping, $\mathrm{RO}$ modules (membrane separation) and a post-treatment system $[83,84]$. Recently, the largest $R O$ desalination plants have been designed and operated in Saudi Arabia, with the production capacities of plants at Yanbu, Al Jubail and Jeddah being $128,000,91,000$ and $56,800 \mathrm{~m}^{3} /$ day, respectively [29].

The PV powered RO system is very sought-after in demonstration plants due to the modularity and easy scalability of both the PV and RO elements [85,86], while solar-thermal RO desalination plants are way behind in terms of the commercialization phase [5]. Research carried out to study the 
application of solar thermal energy for desalination by interlinking an organic Rankine cycle (ORC) with seawater reverse osmosis (ORC-RO) [87] has revealed the benefit of combining an ORC with a desalination system whereby the seawater furnishes a heat sink for the ORC condenser while it is preheated simultaneously to increase the RO membrane permeability, which results in low power consumption [88]. Solar PV and solar organic Rankine cycle operated reverse osmosis units have superior socio-economic and environmental benefits in comparison with diesel generator operated reverse osmosis units [89]. The power usage and water productivity cost of a RO desalination unit relies heavily on the membrane layout, system efficiency and TDS in the feed water [90]. The efficiency of the solar PV powered RO unit depends on the efficiencies of various components [32]. A study conducted at Central Queensland University [91] for optimization of an RO desalination plant found that changes to temperature, pressure or concentrate of feed water results in system improvement, feed flow rate was the only variable that showed improvement in system efficiency of up to $15 \%$ while permeate concentration remained below a potable level of $500 \mathrm{ppm}$.

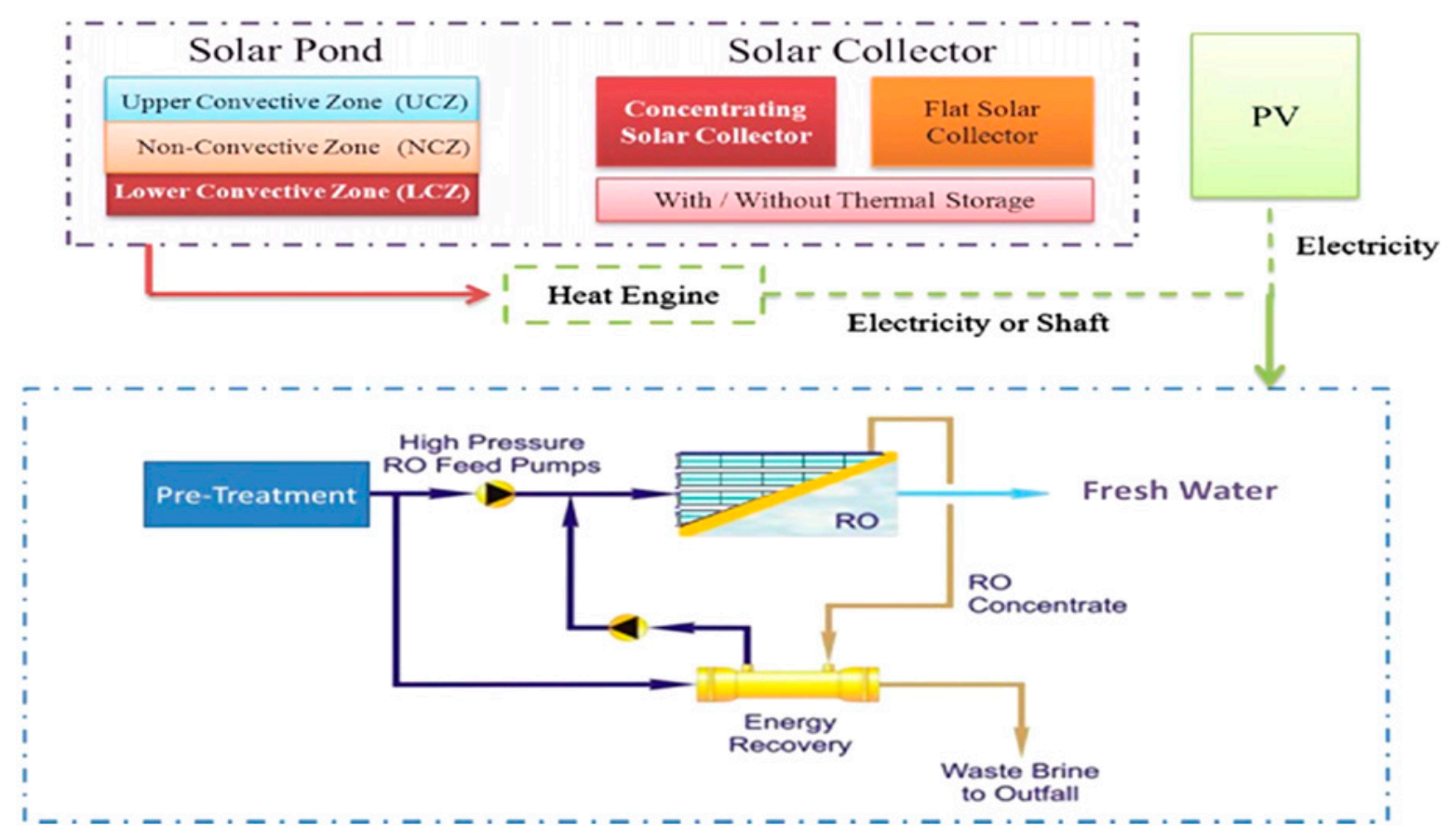

Figure 11. Solar powered RO system [92].

The pressure limit of membrane and attainable recovery rate are two important factors in RO membranes. Feed water has an impact both on water flux and salt rejection rate. Generally, the more the pressure, the higher the rejection of the membrane. Therefore, it is important to fathom the rejection characteristics of each membrane type and ensure that it meets the required quality. As RO membranes are not perfect barriers to dissolved salts in feedwater, there is always some salt passage through the membrane. With increase in feedwater pressure, the salt passage is overcome as water is pushed through the membrane at a faster rate than the salt is transported. However, above a certain pressure level, there is no increase in salt rejection and some salt flow occurs along with water flowing through the membrane. The maximum attainable recovery rate in any RO system does not depend on a limiting osmotic pressure, but rather on the concentration of salts present in the feed water and their inclination to precipitate on the membrane surface as mineral scale [91]. The recovery rate of a membrane system depends on feed water chemistry as different water types contain various concentrations of dissolved salts.

$\mathrm{RO}$, the most energy efficient desalination process basically consumes more energy than conventional fresh water treatment processes due to thermodynamic limitation of separation of saline solutions. Hence, pushing a significant long term saving in energy cost can be achieved by pushing 
the energy consumption towards the thermodynamic limit of separation. Lin and Elimelech [93] studied potential energy reduction for RO desalination using staged operations with both closed circuit configurations (CC-RO) and multi-stage direct pass (DP-RO). The study found that multi-stage DP-RO is considerably more energy efficient than single stage $\mathrm{RO}$, but it is extremely expensive, while, in CC-RO, the capital cost remains the same as the major components of the system are similar to single stage $\mathrm{RO}$ with no heat exchangers used. Although CC-RO has a superior efficiency theoretically compared to single stage $\mathrm{RO}$ and it is easier to implement from an economic point of view than multi stage DP-RO, yet it is still not a technically mature process and it would need further development to explore its true potential by measuring the impact of varying hydraulic pressure on the long term $\mathrm{RO}$ membrane performance.

Advantages and disadvantages of the RO process:

- The material corrosion issues are considerably less in contrast to MSF and MED processes because of atmospheric temperature conditions;

- Recent developments in technology have also reduced the operating expenditure of RO plants in the past decade;

- $\quad$ Polymeric materials are preferred over the metal alloys [94];

- New operational membranes have lower prices and are highly durable;

- Membrane scaling due to precipitation of salts is a common issue in the RO process;

- Membranes are vulnerable to biological fouling due to the formation of micro-organisms and also through entrapment of live and dead organisms, and colloidal fouling which is due to the settlement of colloids from an accumulation of aluminum silicates and clays [94].

\subsubsection{Membrane Distillation (MD)}

In membrane distillation, water vapor penetrates through a hydrophobic membrane due to a difference in temperature, thus disassociating it from the feed water phase. MD is a combination of thermal distillation and membrane desalination. Vapor pressure gradient is the driving force for the MD process which occurs due to temperature difference across the membrane. As the driving force is not pure thermal force, membrane distillation can therefore take place at a considerably lower temperature than the traditional thermal distillation. Molecular water in steam form goes through the membrane from the compartment with substantial vapor pressure to the hot compartment. MD can be categorized in four different configurations, namely air gap membrane distillation (AGMD), sweeping gas membrane distillation (SGMD), direct contact membrane distillation (DCMD) and vacuum membrane distillation (VMD) as illustrated in Figures 12 and 13 [5,95].

Various investigations were carried out to determine: (i) fresh water production rates and the energetic requirements of the different components of the system and found that a DCMD/SGSP (salt-gradient solar pond) coupled system handles roughly six times more water flow than a similar system consisting of an air-gap membrane distillation unit driven by a SGSP. Also, there was a significant heat loss of $30 \%$ in various locations as $70 \%$ heat extracted was utilized to drive thermal desalination. High water fluxes can be achieved if heat losses are minimized [53,96]; (ii) the effect of various geometric and operating frameworks (including system temperature, water flow rate, salt absorption rate, cooling temperature and the diameter of the system layer) on the system performance. The study showed that productivity as well as the efficiency of the system can be achieved through optimization of these operating conditions [53,97]. 


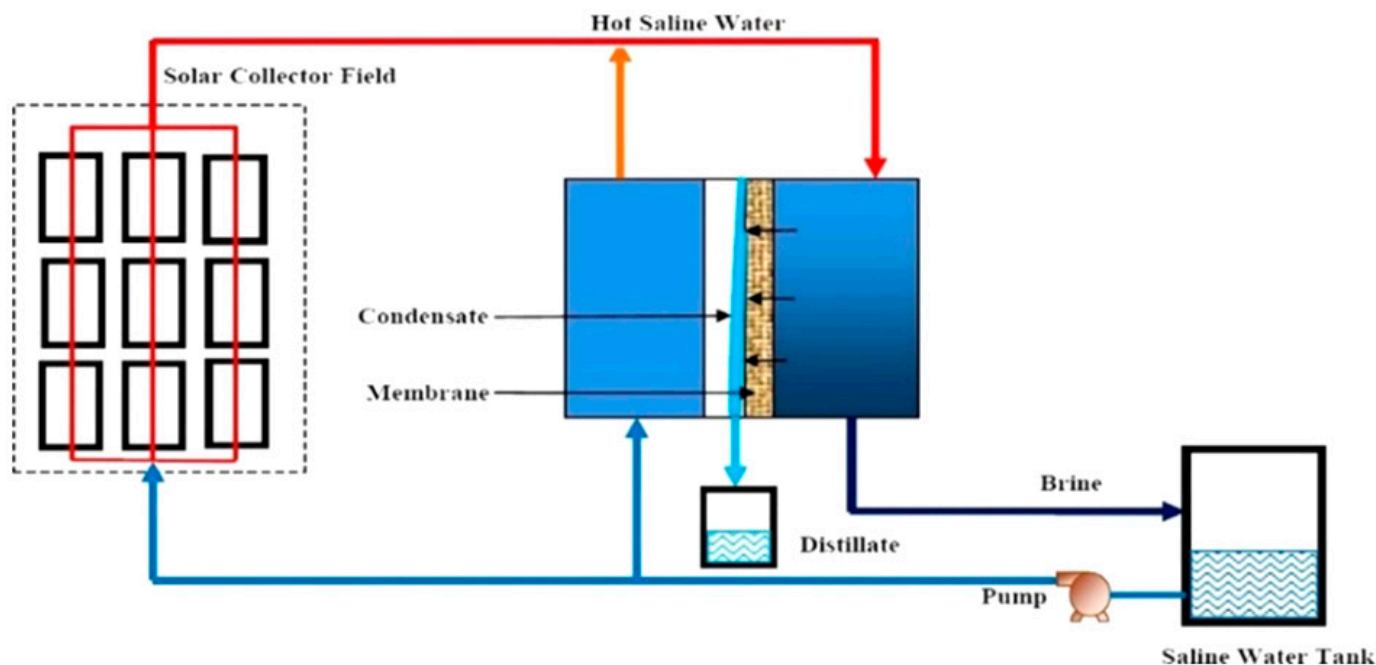

Figure 12. Solar powered membrane distillation [5].
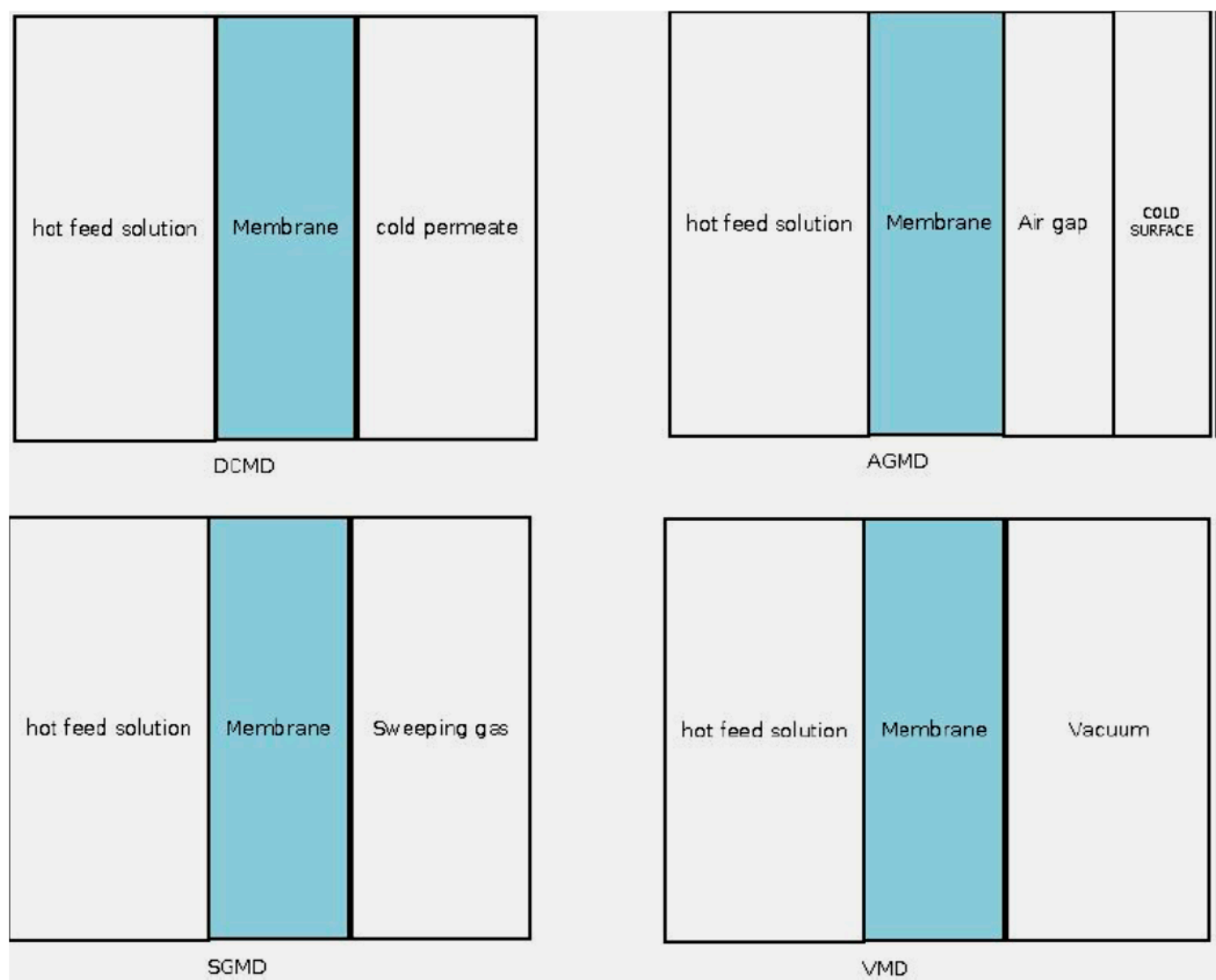

Figure 13. Schematic representation of MD configurations [2].

Membrane distillation can be very competitive economically when low grade heat such as industrial waste heat, solar power and geothermal energy is available [98]. System optimization through incorporation of heat recovery units can help extend MD application to rural regions. Guan et al. [99] studied a direct membrane distillation desalination system coupled with heat recovery using Aspen Plus to optimize the system level heat utilization. They derived an implicit expression of gain output ratio (GOR) to demonstrate the interplay of heat utilization and process parameters. They concluded that a compromize should be made whenever limited thermal energy resources are available and hence a high GOR is desired. Likewise, if there is cheap and abundant waste heat, 
priority should be given to high water production. A higher GOR was achieved with high heat transfer resistance (due to less conductive and thicker membranes).

There are different opinions among researchers when it comes to energy consumption and cost of MD processes. Some researchers are of the view that MD from an energy usage viewpoint is not favorable when compared with MED and MSF due to the fact that there is an additional resistance to mass transport and reduced thermal efficiency (due to heat conductivity losses) offered by the membrane [100], while others are of the view that the MD energy consumption is almost the same as that of MSF plants, but the pumping power is less [101].

Membrane distillation processes have a number of benefits over traditional separation methods in different applications like distillation and evaporation. These are:

- Membrane processes can be easily upgraded to large scale due to their compact and modular design;

- A gentle product treatment is possible due to this energy efficient system operating under moderate temperature conditions.

On the other hand, MD has the disadvantage of membrane wetting, resulting in poor water quality, the lack of specific membrane designs (MD experiments used microfiltration membranes) and a lesser flow in contrast to other desalination technologies [2,102].

\subsubsection{Electro-Dialysis and Electro-Dialysis Reversal (ED/EDR)}

ED is an electrochemical separation process operating at ambient pressure that utilizes an electrical potential to feed salt through an ion-selective membrane, leaving fresh water behind. The TDS are removed from the feed seawater, instead of the reverse, thus making it unique from all the other main desalination processes. As feed water flows through, negative salt ions pass through the anion-porous membrane to a positive electrode, whereas the positive salt ions pass through the cation porous membrane towards a negative electrode. In a conventional photovoltaic electro dialysis (PV-ED) system, electrodes are connected to an outside PV source in a container of salt water, removing water salinity as water passes through ion selective membranes positioned between two electrodes as shown in Figure 14.

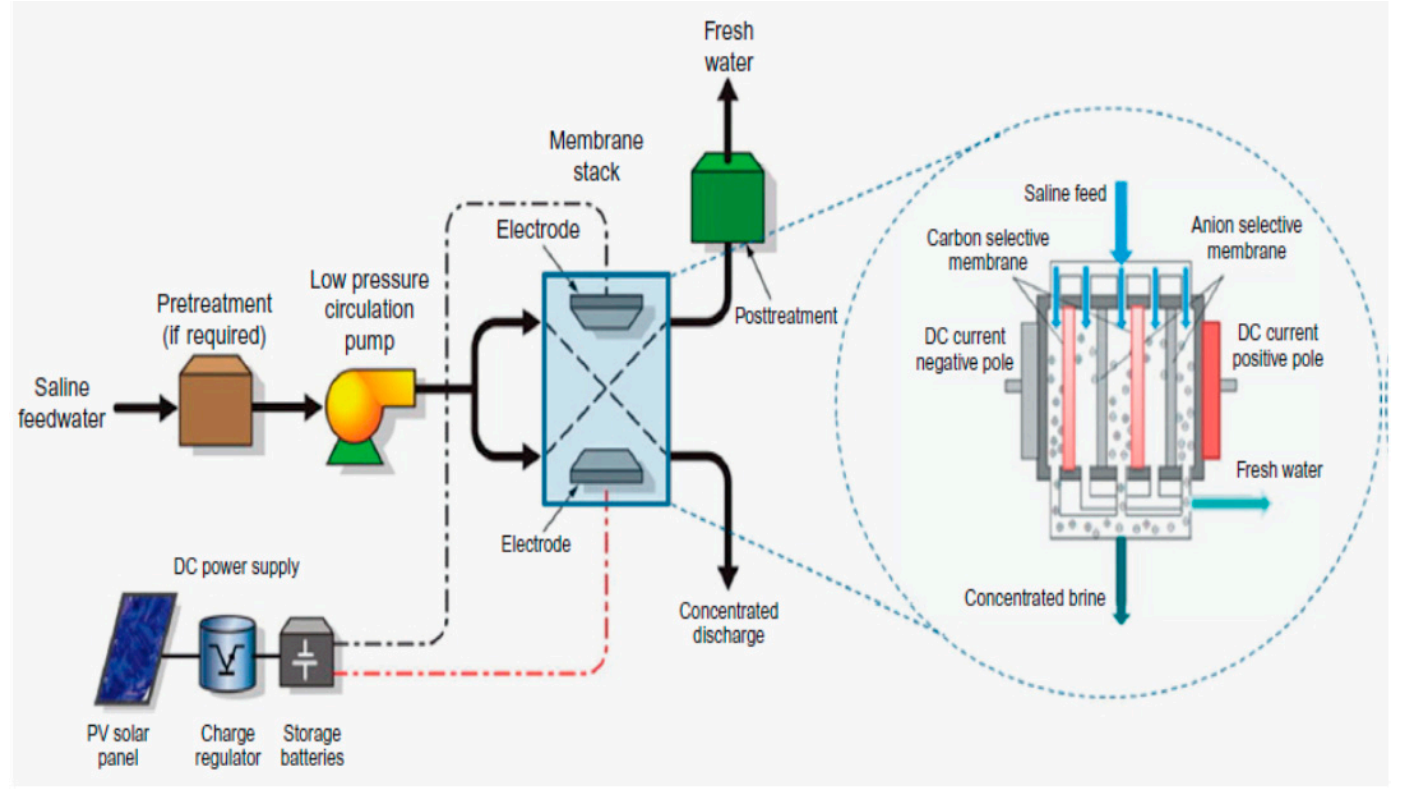

Figure 14. Schematic diagram of a PV/ED system [53].

Integrating solar PV with ED is a promising recently developed technology. Fernadez Gonzalez et al. [96] studied the sustainability of a PV-ED integrated system for fresh water production through 
energy and environmental considerations. They compared PV-ED with a grid connected system and took $\left(0.49-0.91 \mathrm{kWh} / \mathrm{m}^{3}\right)$ energy consumption as a reference for desalination of brackish water (2500-500 $\mathrm{mg} / \mathrm{L}$ ) by PV-ED. It was found that the environmental impact was less than that contributed by the grid energy supply and also that PV-ED might be more cost effective than the conventional grid mix supplied system.

The solar powered ED desalination system is convenient for: (a) areas having little or no electric power, (b) remote areas with no access to low cost fuel supply, and (c) areas with sufficient sunshine hours $[5,103]$.

Electro-Dialysis has the ability to recover more fresh water and produce less brine. Direct current is the major energy requirement for separation of ionic substances in the membrane. Energy use is directly proportional to the salts removed. This process is applicable to brackish water with a salinity less than $6 \mathrm{~g} / \mathrm{L}$ of dissolved solids, but not appropriate for water with dissolved solids less than $0.4 \mathrm{~g} / \mathrm{L}$.

Electro-Dialysis reversal (EDR) is an identical process, in which the cation and anion reverse to regularly alternate current flow. The polarity is alternated 4 times an hour in design applications, thus creating a cleaning mechanism, and reducing the scaling and fouling potential of the membrane. EDR has a higher recovery rate of up to $94 \%$ because of the feed water circulation within the system and the alternating polarity [104].

\subsection{Alternative Processes}

\subsubsection{Freezing}

This process occurs when the temperature of saline water is lowered to its freezing point and thus further heat is removed. Indeed, as the crystal structures grow, the impurities are removed from crystal structures. This process uses the phase change of water from liquid to solid. This process requires the separation of the ice crystals from the brine, cleaning of the ice crystals to remove the adhering salts on the crystals surface, and melting of the ice to produce fresh water [38,105].

Freezing processes are categorized into two groups: direct freezing and indirect freezing processes. In direct freezing, there is direct exchange of heat between the feed seawater and the refrigerant $[105,106]$. The refrigerant evaporates and discharges from the top of the freezer, while the seawater is cooled and then frozen at the same time. Direct freezing has a high production rate but it has very stringent requirements for refrigerant as it has to be chemically inactive, nontoxic, immiscible in water, and resistant to hydrates formation. It requires a very precise refrigerant having a boiling temperature of $-4{ }^{\circ} \mathrm{C}$ or less, non-flammable, inexpensive and commercially available $[107,108]$. The operating temperature for this method is $-5^{\circ} \mathrm{C}$ and is therefore characterized as a low power consumption process [109]. Figure 15 shows a schematic diagram of a direct freezing process where liquid refrigerant enters from the bottom and exits as vapor at the top. It requires a good mixing of refrigerant with the solution to produce ice with less impurities [110]. Saline water $\left(\mathrm{NaCl}-\mathrm{H}_{2} \mathrm{O}\right)$ is used as a refrigerant.

In indirect freezing, saline water is not in direct contact with the refrigerant. Ice forms on a surface by mechanical refrigeration or other methods as illustrated in Figure 16. The energy requirements are high because of the resistance of the surface between the saline water and refrigerant. Large metallic heat transfer surfaces are needed for both freezing and melting steps. This process is hardly used in practice. The merits of this technology are a lower theoretical energy requirement, very low corrosion potential and slight scaling or salt precipitation. This process can produce drinking water and also water for irrigation. However, this process involves handling of ice and water which are mechanically difficult and complex to move and process $[105,111]$. 


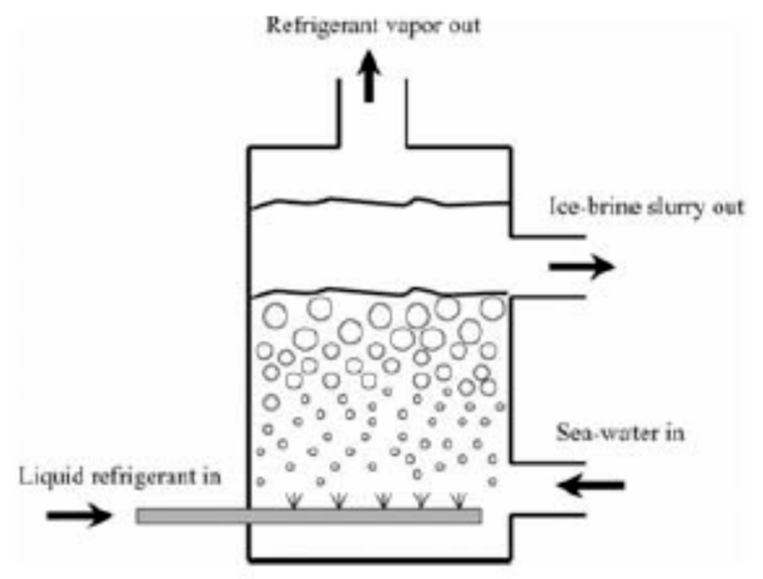

Figure 15. Direct freezing [110].

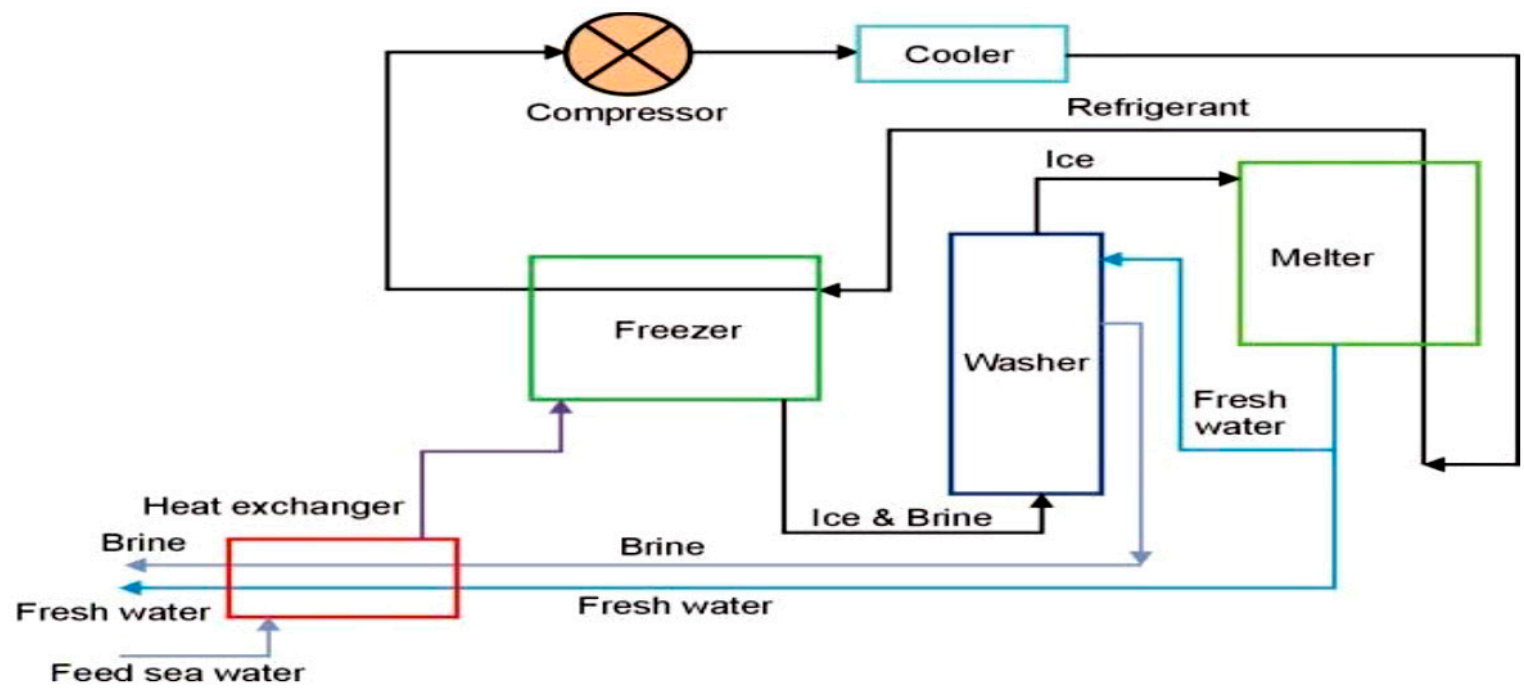

Figure 16. Indirect freezing process [105].

\subsubsection{Ion Exchange}

This technology is generally in use for water softening along with other utilizations. The ion-exchange system can best be related as exchange of ions between a solid phase and a liquid phase surrounding the solid. Chemical resins (solid phase) are designed to substitute their ions with the liquid phase (feed water) ions, resulting in the purification of water. Salty feed water is allowed to pass over resin beads where salt ions from the feed water are replaced for other ions. The process eliminates $\mathrm{Na}+$ and $\mathrm{Cl}$ ions from the feed water, thus resulting in potable water [104,112]. Ion exchange is used in conjunction with reverse osmosis processes such as blending water treated by ion exchange with RO product water for an increase in water production. Ion exchange is a beneficial process in order to completely demineralize water in high purity requirement applications such as in high-pressure boilers. Unfortunately, it is not a cost-effective process for treating brackish or seawater.

\section{Environmental Impacts of Desalination}

Desalination plants play an important role in addressing the fresh water needs of a large portion of the population around the world, but these technologies also have some dire environmental consequences attached to them. These adverse impacts are largely due to: (a) leaking of seawater intake pipelines, which eventually causes damage to aquifers, (b) brine and pre-treatment chemical disposal affecting marine ecosystems, and (c) increased greenhouse gas emissions due to large energy 
consumption [113,114]. The effects of various factors impacting the environment due to desalination are discussed in the following sections.

\subsection{Salinity, Temperature and Density}

Salinity increases in the waste stream of all desalination processes, but high temperature values are a salient feature of distillation plant effluents only [115]. The reverse osmosis brine has a higher density compared to seawater due to its higher salinity and will, therefore, most likely have an impact on benthic communities, whereas distillation plant discharges tend to drift on the surface, thus hindering productivity in pelagic communities $[116,117]$. The positive buoyancy of distillation plant discharges result in discharge of huge volumes of cooling water that is mixed with the brine. Various desalination pollutants are discussed in detail below.

\subsection{Chlorine}

Chlorine is one of the prime pollutants of desalination processes due to its addition in desalination plant feed water to prohibit biofouling on heat exchanger surfaces. Chlorine is a powerful oxidizing agent and a very effective biocide, and modern desalination plants mostly operate on polyamide membranes that are susceptible to oxidizing chemicals like chlorine. Any residual levels in the discharge are harmful to marine life. The use of chlorine could also lead to formation of oxidation by-products such as halogenated organics, which are quite common in the marine environment and there is evidence that some of them are carcinogenic to animals $[118,119]$.

\subsection{De-Aeration and Oxygen Scavengers}

Oxygen solubility in seawater decreases with increase in temperature and salinity. However, to stop corrosion, oxygen levels in distillation is decreased through physical de-aeration and the addition of oxygen scavengers like sodium bisulphite. The exhaustion of oxygen is also a problem of RO brine due to the fact that sodium bisulphite is generally used as a neutralizing agent for chlorine. The lack of dissolved oxygen could be lethal to marine organisms and aeration is advized before oceanic discharge $[117,120]$.

\subsection{Heavy Metals}

Waste brine may contain a low number of heavy metals that pass into solution when corrosion occurs on the interior surfaces of desalination plants. Brine metal compositions rely on the use of various construction materials in desalination and RO plants; for example, copper contamination is a big issue in desalination plants due to the fact that copper-nickel alloys are mostly used for heat exchanger surfaces [121]. On the other hand, RO brine may have traces of iron, nickel, chromium and molybdenum as non-metal equipment and steel alloys are used in these plants [122]. These heavy metals have a tendency to mix in suspended material and eventually in sediments, thus affecting areas of restricted water exchange and soft bottom habitats. Many benthic invertebrates nourish on these suspended and deposited materials, which may result in passing these enriched metals in their bodies on to higher trophic levels. Hence, establishing limits for heavy metal concentrations in the brine discharges is highly recommended [123].

\subsection{Coagulants and Coagulant Aids}

Coagulants and coagulant aids are supplementary methods to improve coagulation. Coagulants such as aluminum chloride, ferric sulfate, and ferric chloride are utilized to enhance filtration of suspended particles from $\mathrm{RO}$ feed water, while coagulant aids are organic substances with high molecular masses that hold particles together. Toxic effects of coagulants and coagulant aids are not expected if the filter backwash discharges into the sea. Nonetheless, increased turbidity in discharge may result in reduced primary production or burial of sessile organisms. Impact mitigation options 
are to dilute the backwash by continuous blending with the brine, or remove it from the filters and transport it to a landfill [116,118].

\subsection{Antiscalants}

To prohibit scale formation, antiscalants are added to the feed water in both distillation and RO plants as scaling on heat exchanger surfaces, inside tubes or even on RO membranes, reduces plant efficiency. The major accomplices of antiscalants are organic polymers rich with carboxylic like poly-acrylic acid and polymaleic acid. Environmental risk associated with the release of antiscalants into the marine environment is reasonably low due to their low toxicity. However, dispersal and comparatively long residence times must be anticipated due to the poor degradability of these antiscalants which presents a possible risk of interference with element cycles of trace metals [116,124].

Stringent guidelines for environmental protection should be put in place not only to help optimize both existing and proposed desalination facilities, but also to ensure nations and consumers can enjoy benefits of the expanded access to desalinated water with assurance of quality, safety and environmental protection [125]. It is important that the intake and pre-treatment of seawater, as well as the discharge of the concentrated reject water produced by the specific conditions at the site of every desalination plant should be controlled. Thus, it is crucial to contemplate and assess the benchmarks that assist in the selection of the best available technology and the best and safest solution for the intake and outfall system at every plant. These environmental aspects are as equally important as the commercial details and must be taken into account, not only in the design and construction phases, but also during plant operation $[9,126]$.

The critical and essential factors in regards to the environmental impact requirements that should therefore be taken into account for different desalination options are [9,125,127]:

- Standards for wastewater discharge; ensure to eliminate harm to the environment as far as possible by regulating activities, substances and services that may result in environmental harm due to wastewater discharge;

- Air pollution control needs; air pollutants emitted by desalination plants are $\mathrm{NO}, \mathrm{CO}, \mathrm{SO}_{2} \mathrm{CO}$ and $\mathrm{CO}_{2}$. These can be eliminated through installation of $\mathrm{NO}_{\mathrm{x}}$ burners, air filters, particulate wet scrubbers, etc.;

- Concentrate discharge standards and locations;

- Noise control guidelines;

- Public services and utilities;

- Land use;

- Artistic light and glare.

\subsection{Total Equivalent Warming Impact (TEWI)}

TEWI is a measure of the global warming impact of equipment based on the total related emissions of greenhouse gases during the operation of the equipment and the disposal of the operating fluids at the end of life. TEWI reflects both direct fugitive emissions and indirect emissions through energy consumption in equipment operation. It is measured in $\mathrm{kg}$ of carbon dioxide equivalent $\left(\mathrm{CO}_{2}-\mathrm{e}\right)$.

The KYOTO protocol dictates the continuous careful consideration and evaluation of energy consumption activities. This method computes the total relevant greenhouse gases emission for certain applications like refrigeration and air-conditioning. It is worthwhile to mention that electricity generation to power stationary refrigeration and air-conditioning equipment is the largest contributor to global warming. For example, this type of equipment used $22 \%$ of all the electricity sent out in Australia in 2006, which resulted in 7\% (40 Metric tons of $\mathrm{CO}_{2}-\mathrm{e}$ ) of all greenhouse gas emissions in Australia [128]. 


\subsection{Greenhouse Gases (GHGs):}

Human activities have resulted in warming of the planet due to greenhouse gases emissions in the atmosphere. The GHGs emitted due to human activities are shown in Figure 17a, i.e., carbon dioxide $\left(\mathrm{CO}_{2}\right)$, methane $\left(\mathrm{CH}_{4}\right)$ nitrous oxide $\left(\mathrm{N}_{2} \mathrm{O}\right)$ and fluorinated gases (F-gases), while Figure $17 \mathrm{~b}$ highlights the top GHG emitting countries, i.e., China, United States of America, the European Union, India, the Russian Federation and Japan. These GHGs remain in the atmosphere from a few weeks to thousands of years. The effects of these increased levels of GHGs include rise in temperatures, weather pattern changes, rising sea levels, increased public health risks (i.e., health related illnesses and deaths), dangers from storms and flooding, etc. [129].

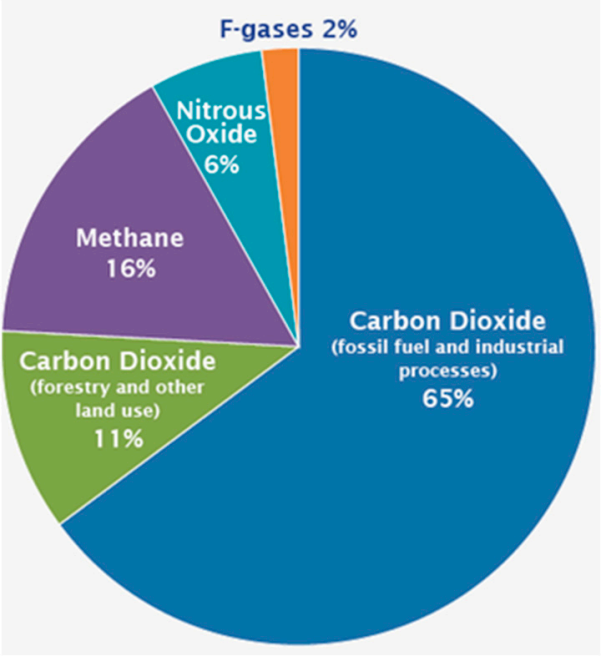

(a)

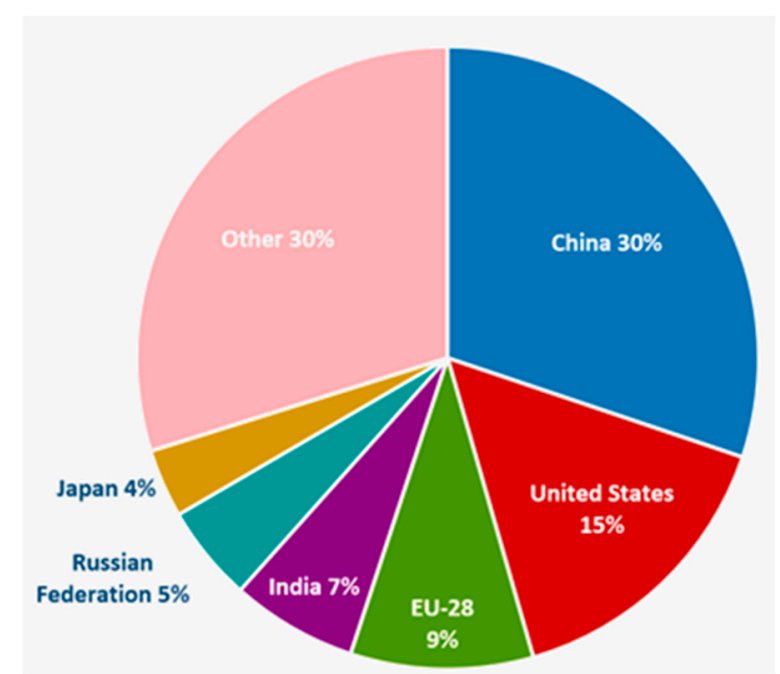

(b)

Figure 17. Global GHGs: (a) Emission by gas, and (b) Emission by country [129].

Environmental impacts of intake systems for desalination plants are impingements and entrainment of marine organisms, construction and facility operation [130]. In fact impingement and entrainment of marine organisms, a function of design, operation and local marine biology at the intake head, is a serious environmental concern in relation to surface intake systems [131]. There are environmental regulations in place which govern mitigation of marine life impacts for almost all projects. One way to minimize the impact is to adopt subsurface intake, which extracts seawater from under the sea level or beach using sand as a filter. This can further reduce energy usage and chemicals used, and therefore results in cost reduction [132].

There have been studies conducted to assess the environmental risks posed by outfall systems in relation to the disposal of concentrate. Environmental impacts of outfall systems include increase in the salinity of receiving water bodies, discharge of chemicals used in pre-treatment and membrane cleaning and discharge of metals from corrosion $(\mathrm{Fe}, \mathrm{Mo}, \mathrm{Ni}, \mathrm{Cr}$ ) to mention a few. There are different methods of brine treatment, but zero liquid discharge garnered renewed interest because these are environmental friendly means for concentrate disposal at sites (particularly in inland areas) where other more conventional concentrate disposal options are not economically applicable [131]. Zero liquid discharge (ZLD) is a wastewater management strategy that eliminates liquid waste and enhances water usage efficiency [133]. Jeppesen et al. [134] thoroughly investigated the recovery of commercial salt in a ZLD system and came up with the conclusion that it may be financially viable to recover different metals like sodium, magnesium, potassium, rubidium and indium, etc., through the ZLD process in areas where there is a demand for such metals/salt locally. As the demand rises, the value of these metals and the extraction cost may eventually become profitable to offset the zero liquid desalination cost. Whenever there are considerable concentrate discharge impacts based on best possible design and scenarios, mitigation measures such as pre or post operation of the desalination 
facility can be put in place to counter the impacts. A similar strategy can be adopted for impingement and entrainment mitigation

\section{Economics of Solar Desalination Processes}

Desalination is an expensive process. For example, the cost of $3.78 \mathrm{~m}^{3}$ (1000 gallons) of fresh water from a desalination plant ranges between US $\$ 2.50$ to US $\$ 5$ compared to US $\$ 2$ for conventional fresh water $[135,136]$. Desalination plants around the globe use more than 200 million kWh every day, with energy costs approximately $55 \%$ of the plants' total operation and maintenance (O\&M) costs [137]. The reverse osmosis (RO) plants consume 3 to $10 \mathrm{kWh}$ of energy to produce one $\mathrm{m}^{3}$ of fresh water from seawater [138]. In contrast, conventional potable water treatment plants usually consume well under $1 \mathrm{kWh} / \mathrm{m}^{3}[135,139]$. The substantial growth of desalination capacity in recent years is not only because of increased water demand, but also due to the considerable reduction in desalination cost as a result of remarkable technological advances that have resulted in making desalinated water cost-effective with other water sources $[29,39,140]$. The important factors that influence policy/decision makers for appropriate technology selection are the total investment and produced water costs, the type of project contract, and other parameters such as local incentives or subsidies [141]. Desalinated water costs per cubic meter can be substantially impacted by several factors like capacity and type of desalination plant, feed water (seawater or brackish water) and labor, location, and type of energy used whether conventional or renewable energy $[142,143]$. For example, phase change desalination processes that use traditional sources of fuel and energy generally have large production capacities and are very expensive compared to membrane plants due to the requirement of large quantities of fuel for vaporizing saltwater. In the instance of the Ashkelon seawater reverse osmosis (SWRO) plant, the overall fresh water cost was US $\$ 0.52 / \mathrm{m}^{3}$ [144]. Similarly, membrane methods are more cost effective for brackish water desalination. The comparison is illustrated in Figure 18, where cost approximations for large-scale commercial plants for $\mathrm{RO}$ and thermal desalination are presented, including the cost of waste management $[9,144,145]$. The membrane based desalination process has replaced the thermal based desalination process due primarily to its lower energy consumption, lightweight and compact design and high productivity. Membrane processes require electricity as the main energy input compared to thermal desalination processes which require both waste heat and electricity as an energy source. Hence, a solar energy powered membrane based desalination system makes desalination more justifiable and environmentally friendly [146].

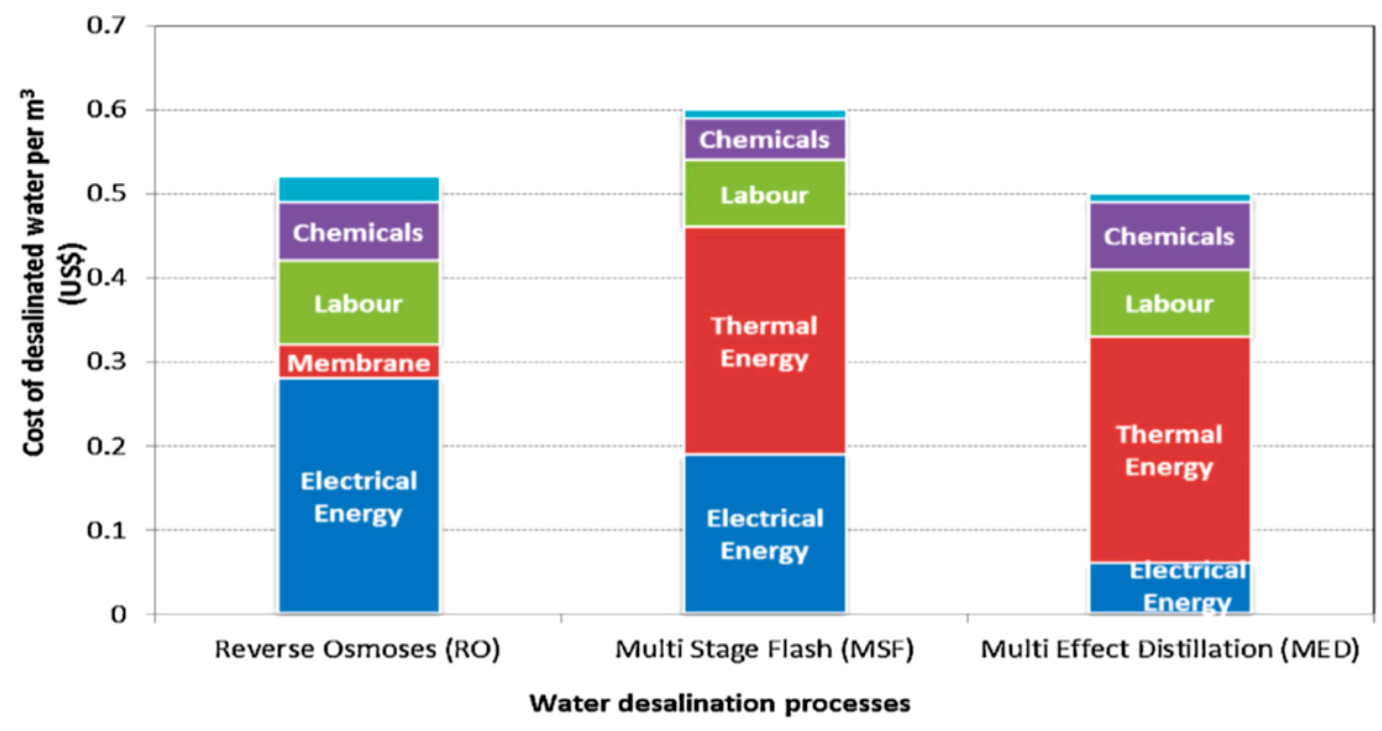

Figure 18. Cost of RO and thermal desalination processes [144,145]. 
Membrane desalination technologies such as $\mathrm{RO}$ are considered to be less energy intensive as compared to thermal technologies, and these can be further reduced by incorporating energy recovery systems. The type and composition of the feed water influences the cost of water desalination in membrane processes. Large-scale $\mathrm{RO}$ facilities can utilize brackish water with total dissolved solids ranging from 2000 to 10,000 ppm, but higher TDS concentrations result in a higher unit cost of the desalinated water as shown in Figure 19 [9,147].
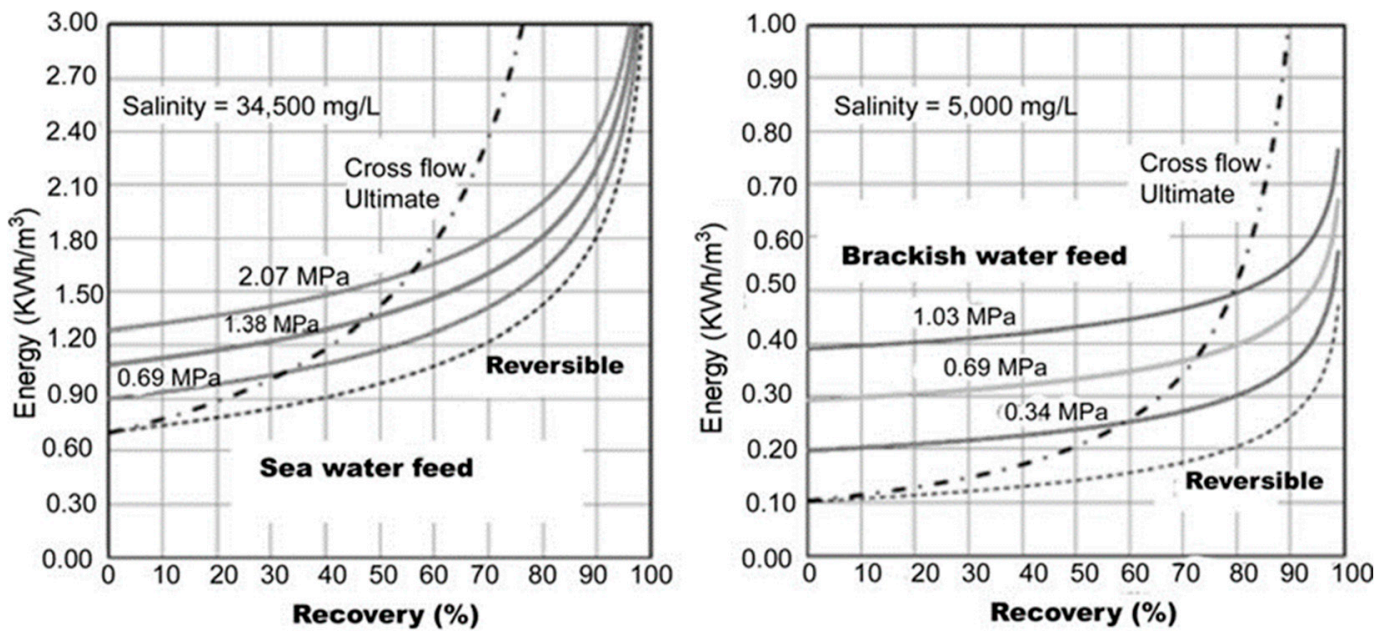

Figure 19. Energy requirement of RO desalination (Seawater \& brackish water feed) [9].

Cost of waste management in this instance was included in the calculations. For seawater desalination, the RO method has been used extensively recently due to technological improvements which have resulted in reduction of the cost of membranes. For example, in the Ashkelon seawater reverse osmosis (SWRO) plant, the largest in the world with a capacity of $330,000 \mathrm{~m}^{3}$ per day, the estimated cost of fresh water is US $\$ 0.52 / \mathrm{m}^{3}$, while in another RO plant in Tampa Bay USA with a capacity of $94,600 \mathrm{~m}^{3} /$ day, the cost of water produced is US $\$ 0.56 / \mathrm{m}^{3}[6,9,144]$. From Table 1 , it is obvious that the costs are higher for small-scale RO operations. As the plant capacity increases, the prices reduce considerably from US $\$ 1.25-3.93$ for a plant capacity of $15,000 \mathrm{~m}^{3} /$ day to US $\$ 0.45-0.66$ with a plant capacity of $100,000-320,000 \mathrm{~m}^{3} /$ day. Similarly, the cost of brackish water RO ranges from US $\$ 0.78-1.33 / \mathrm{m}^{3}$ to US $\$ 0.26-0.54 / \mathrm{m}^{3}$ for plant capacities ranging from $20-1200 \mathrm{~m}^{3} /$ day to $40,000-46,000 \mathrm{~m}^{3} /$ day.

Table 1. Membrane vs thermal desalination cost per feed water source and production capacity, adapted from [148].

\begin{tabular}{ccc}
\hline Feed Water & Plant Desalination $\mathbf{~}^{\mathbf{3}}$ /day) & Desalination Cost $/ \mathbf{m}^{\mathbf{3}}$ (US $\$$ ) \\
\hline \multirow{2}{*}{ Seawater RO } & Less than 100 & $1.5-18.75$ \\
& $250-1000$ & $1.25-3.93$ \\
& $15,000-60,000$ & $0.48-1.62$ \\
Brackish water RO & $100,000-320,000$ & $0.45-0.66$ \\
\hline \multirow{2}{*}{ MSF (multi-stage flash) } & Less than 20 & $5.63-12.9$ \\
& $20-1200$ & $0.78-1.33$ \\
& $40,000-46,000$ & $0.26-0.54$ \\
\hline MED (multi-effect distillation) & Less than 100 & $2.20-8.80$ \\
VCD (vapor compression) & $12,000-55,000$ & $0.84-1.31$ \\
\hline
\end{tabular}


On the other hand, thermal process desalination plants mostly use fossil fuels to function, resulting in higher unit costs of desalinated water. For multi-stage flash (MSF), the cost for large systems with daily production exceeding $91,000 \mathrm{~m}^{3}$ ranges from US $\$ 0.46-0.89 / \mathrm{m}^{3}$ as per Table 1 . For multi-effect distillation (MED), the cost for large installations with a production of $91,000-528,000$ $\mathrm{m}^{3} /$ day varies between US $\$ 0.46$ and $1.54 / \mathrm{m}^{3}$. The cost of the vapor compression process ranges from US $\$ 1.77-2.34 / \mathrm{m}^{3}$ for plant production ranging from $1000-1200 \mathrm{~m}^{3} /$ day $[148,149]$.

The energy cost of the desalination units can be decreased through integration of desalination units with renewable energy sources. A comparison of water production cost of solar powered desalination plants with conventional energy plants is shown in Table $2[148,150,151]$. The unit price of solar powered desalinated seawater of US $\$ 3.45-9.9 / \mathrm{m}^{3}$ is very high compared to conventional fossil fuel powered desalinated water costs of US $\$ 0.38-2.97 / \mathrm{m}^{3}$. For brackish water, the unit cost of desalinated water through conventional energy is between US $\$ 0.23-1.17 / \mathrm{m}^{3}$, while that of solar energy powered desalinated water is in the range of US $\$ 4.95-11.35 / \mathrm{m}^{3}$ [6]. It is evident that solar energy powered installations are currently less profitable than conventional fossil fuel powered installations due to the high cost of solar collector/PV panels. Nevertheless, these installations produce little to no $\mathrm{CO}_{2}$ emissions that is the main global warming contributor causing the Earth's average surface temperature to rise. Renewable energy sources like solar/wind essentially do not require water to operate like fossil fuel energy sources and, therefore, don't pollute water resources or strain supplies. The cost of desalinated water, especially from brackish water using RO, is expected to be less than for any other conventional fossil fuel based technologies in the future due to its much lower energy consumption. It is also believed that desalination cost will gradually decrease by about $4 \%$ to $5 \%$ every year due to the rapid improvement of technology which has resulted / shall result in cheaper membranes and energy recovery systems [152,153]. Hence, there is tremendous scope for integrating solar energy resources into desalination plants which will make the unit price of desalinated water cost effective in solar energy abundant areas. It will also result in environmentally friendly plants.

Table 2. Cost of desalination water produced per feed water and energy sources, adapted from [150].

\begin{tabular}{ccc}
\hline Feed Water Source & Energy Source & Cost $\left(\mathbf{U S ~} \$ / \mathbf{m}^{\mathbf{3}}\right)$ \\
\hline \multirow{3}{*}{ Seawater } & Conventional energy & $0.38-2.97$ \\
& Photovoltaics panels energy & $3.45-9.9$ \\
& Wind power & $1.1-5.5$ \\
\hline \multirow{3}{*}{ Brackish water } & Conventional energy & $0.23-1.17$ \\
& Photovoltaics panels energy & $4.95-11.35$ \\
& Geothermal energy & 2.2 \\
\hline
\end{tabular}

\section{Discussion}

Water and energy are basic needs of all humans living on this planet. Access to sufficient quantities of safe water for daily use is critical to health and wellbeing, and also provides the opportunity to achieve prosperity and development. However, many regions in the developing countries suffer from severe fresh water and energy shortages. An estimated 1.8 billion people worldwide still do not have access to potable water. Unfortunately, there are not only shortages of fresh water resources, but these are also not equally distributed around the globe. The best way of dealing with this situation for mankind is to find some alternative ways of fresh water production. Fortunately, desalination technology has the capability to handle this problem. There are approximately 18,436 desalination plants worldwide according to the International Desalination Association (IDA) with a global commissioned capacity of 92.5 million $\mathrm{m}^{3}$ /day catering for the water needs of more than 300 million people who are dependent on desalinated water for some or most of their daily fresh water requirements. At the same time, however, desalination plants consume a lot of energy and there are also negative environmental impacts associated with them. 
The use of renewable energy for desalination has become a reality, especially solar energy that is a technically mature and viable alternative option to cope with deteriorating fossil fuel supplies and fluctuating prices in recent years and offers a sustainable solution for water scarcity. The main thermal and membrane-based desalination processes were thoroughly reviewed in this article. Membrane based solar desalination has a promising future as the considerable advancement in the design of membrane modules, pre-treatment methods and energy recovery options have enabled these processes to be cost competitive with thermal processes. The membrane based desalination process has replaced the thermal based desalination process in many parts of the world due to lower energy consumption. Membrane distillation is the most energy efficient desalination process which basically consumes more energy than conventional fresh water treatment processes. Membrane processes can be easily upgraded to large scale because of the compact and modular nature/design. Membrane distillation can be very competitive economically when low grade heat such as industrial waste heat, solar power and geothermal energy is available Therefore, solar based desalination could be a promising prospect in the Middle East and African countries where solar energy is in abundance throughout the year.

Large-scale desalination projects can have major environmental impacts during construction and operation similar to any major project. Desalination may produce high-quality water, but may also end up introducing harmful biological or chemical contaminants into our water supply. All water from desalination plants must be monitored and regulated to ensure safe public and marine health. Further research into identifying all contaminants in desalination brines and the mitigation of impacts of brine discharge is needed. There should be no brine disposal in underground aquifers until in-depth and expert groundwater surveys are carried out and there is no potential risk of brine plumes appearing in fresh water wells.

Desalination costs are currently higher than fossil fuel-based desalination, but studies show that these prices are decreasing due to technological improvements. There are many factors which influence desalination, making estimates uncertain and comparisons harder. The notion that desalination costs will decrease could go horribly wrong and further cost reductions may therefore not be possible, and costs could actually increase in future. Hence, predicted costs must be rationalized over the lifespan of the facility, including reasonable allowances for energy cost and construction materials, limits to membrane performance, and other relevant components.

Solar energy has the capacity to make the desalination industry greener and reduce the impacts of environmental risks. Environmental impacts of intake systems and outfall systems in desalination pose a significant threat to the environment. There are different methods such as substrate intake and ZLD, etc., available to minimize such impacts. These methods may currently be costly, but further research may bring the costs down in the long run. In order to achieve that, a far reaching and collective approach towards research and development programs is required, which includes all shareholders, i.e., government policy makers, local communities, consumers, industries, universities and research institutions. These programs must come up with sustainable water desalination policies and strategies to better handle water scarcity issues, and prevent the rapid deterioration of fresh water resources worldwide. Such measures could comprize of technologies with optimal process optimization to minimize waste and energy consumption.

\section{Conclusions}

The use of solar energy for desalination not only has promising prospects, but is also a technically viable option to cater for the stressing energy and water issues. Solar energy powered installations are currently not comparable with conventional fossil fuel installations due to the high cost of solar collector/PV panels. Desalination costs are decreasing continuously for solar thermal technologies, especially in $\mathrm{RO}$ technology, due to the high growth rate in plant capacity and better process design, better and efficient membranes and materials etc. Nevertheless, the author is of the view that desalination costs may not decrease in the future despite technological advancement in existing technology due to rising costs of energy, raw materials and future operating costs. For seawater, energy 
consumption and water production cost in the RO system is less than distillation based methods (MED, MSF, and VCD) due to RO's high productivity in the recovery tools, technical improvement in membrane production, reliable scaling management and greater effectiveness in pumps. For brackish water, $\mathrm{RO}$ and ED-PV are the most economical membrane based desalination systems. RO minimize the marine life impacts from intakes through various technological (physical barriers and behavioral deterrents), design (improving the recovery rate of desalination facility, locating the intake in areas of low biological productivity), and operational measures. Impacts of desalinated brine on the marine environment are largely unknown and should, therefore, be further explored. Further research into substrate intake methods and ZLD methods to make them cost effective is needed. Regulators must enforce zero tolerance policies in relation to ongoing effluent water quality monitoring programs at existing and new desalination plants.

This review was conducted as a part of the research of integration of solar thermal desalination into existing grid infrastructure in the Australian context. The objective of the proposed research is to investigate the economic aspects of chosen integration options, and shall therefore be instrumental in providing an understanding of the extent to which such integration costs increase the total costs of energy supply.

Author Contributions: I.U. extensively reviewed the literature and drafted the manuscript and M.G.R. provided feedback and critical comments for inclusions and finally helped in revising the manuscript to improve the quality of paper.

Funding: This research received no external funding.

Acknowledgments: The authors would like to acknowledge and express their thanks to Tim McSweeney, Adjunct Research Fellow, School of Engineering and Technology, Central Queensland University, Australia for his contribution in proof reading the manuscript.

Conflicts of Interest: The authors declare no conflict of interest.

\section{References}

1. Amy, G.; Ghaffour, N.; Li, Z.; Francis, L.; Linares, R.V.; Missimer, T.; Lattemann, S. Membrane-based seawater desalination: Present and future prospects. Desalination 2017, 401, 16-21. [CrossRef]

2. Azevedo, F.D.A.S.M. Renewable Energy Powered Desalination Systems: Technologies and Market Analysis; Departamento de Engenharia Geográfica, Geofísica e Energia, Faculdade de Ciências, Universidade de Lisboa: Lisbon, Portugal, 2014.

3. WHO/UNICEF Joint Monitoring Programme for Water Supply and Sanitation. 2014. Available online: http://www.unwater.org/publication_categories/whounicef-joint-monitoring-programme-forwater-supply-sanitation-hygiene-jmp/ (accessed on 25 August 2018).

4. Mohammed, M.B. Final Technical Report: Low Cost Nanomaterials for Water Desalination and Purification; United Nations, Educational, Scientific and Cultural Organisation (UNESCO): Paris, France, 2011.

5. Sharon, H.; Reddy, K.S. A review of solar energy driven desalination technologies. Renew. Sustain. Energy Rev. 2015, 41, 1080-1118. [CrossRef]

6. Al-Karaghouli, A.; Kazmerski, L.L. Energy consumption and water production cost of conventional and renewable-energy-powered desalination processes. Renew. Sustain. Energy Rev. 2013, 24, 343-356. [CrossRef]

7. Garg, M.C. Chapter 4-Renewable Energy-Powered Membrane Technology: Cost Analysis and Energy Consumption. In Current Trends and Future Developments on (Bio-) Membranes; Basile, A., Cassano, A., Figoli, A., Eds.; Elsevier: Amsterdam, The Netherlands, 2019; pp. 85-110.

8. Hoff, H. Global water resources and their management. Curr. Opin. Environ. Sustain. 2009, 1, 141-147. [CrossRef]

9. Shatat, M.; Worall, M.; Riffat, S. Opportunities for solar water desalination worldwide: Review. Sustain. Cities Soc. 2013, 9, 67-80. [CrossRef]

10. Ghaffour, N. The challenge of capacity-building strategies and perspectives for desalination for sustainable water use in MENA. Desalin. Water Treat. 2009, 5, 48-53. [CrossRef] 
11. Isaka, M. Water Desalination Using Renewable Energy; IEA-ETSAP (International Energy Agency-Energy Technology Systems Analysis Programme): Paris, France; IRENA (International Renewable Energy Agency): Abu Dhabi, UAE, 2012.

12. Policy Development and Studies Branch (PDSB). Water Scarcity and Humanitarian Action: Key Emerging Trends and Challenges; Policy Development and Studies Branch, UN Office for the Coordination of Humanitarian Affairs (OCHA): New York, NY, USA; Geneva, Switzerland, 2010.

13. Griffin, M. Drought Prompts Australia to Turn to Desalination Despite Cost. 2013. Available online: https:// www.eco-business.com/news/droughts-prompts-australia-to-turn-to-desalination-despite-cost/ (accessed on 16 October 2016).

14. Van Dijk, A.I.J.M.; Beck, H.E.; Crosbie, R.S.; de Jeu, R.A.M.; Liu, Y.Y.; Podger, G.M.; Timbal, B.; Viney, N.R. The Millennium Drought in southeast Australia (2001-2009): Natural and human causes and implications for water resources, ecosystems, economy, and society. Water Resour. Res. 2013, 49, 1040-1057. [CrossRef]

15. Department of Agriculture, Fisheries and Forestry National Dryland Salinity Program (Australia) URS Australia. Introduction to Desalination Technologies in Australia Summary Report; Australian Capital Territory-Federal/National: Canberra, Australia, 2002.

16. International Desalination Association (IDA). Desalination by the Numbers. 2015. Available online: http: / /idadesal.org/desalination-101/desalination-by-the-numbers/ (accessed on 28 February 2018).

17. IDA, GWI. IDA Desalination Yearbook 2017-2018; Media Analytics Ltd.: Oxford, UK, 2017.

18. Zarzo, D.; Prats, D. Desalination and energy consumption. What can we expect in the near future? Desalination 2018, 427, 1-9. [CrossRef]

19. Voutchkov, N. Desalination-Past, Present and Future; International Water Association: London, UK, 2016.

20. ICTD, Department of Field Support Cartographic Section. UN Geospatial Information Section. Middle East Region. 2015. Available online: http://www.un.org/Depts/Cartographic/map/profile/mideastr.pdf (accessed on 28 November 2018).

21. Yatesenvser. Desalination Market Outlook. 2013. Available online: https://yatesenvironmentalservices. wordpress.com/2013/02/26/desalination-market-outlook/ (accessed on 15 March 2018).

22. FICHTNER. MENA Regional Water Outlook Part II Desalination Using Renewable Energy; FICHTNER: Stuttgart, Germany, 2011.

23. Giwa, A.; Dufour, V.; Marzooqi, F.A.; Kaabi, M.A.; Hasan, S.W. Brine management methods: Recent innovations and current status. Desalination 2017, 407, 1-23. [CrossRef]

24. Ghaffour, N.; Missimer, T.M.; Amy, G.L. Technical review and evaluation of the economics of water desalination: Current and future challenges for better water supply sustainability. Desalination 2013, 309, 197-207. [CrossRef]

25. Shahzad, M.W.; Burhan, M.; Ang, L.; Ng, K.C. Energy-water-environment nexus underpinning future desalination sustainability. Desalination 2017, 413, 52-64. [CrossRef]

26. Virgili, F.T.P.; Gasson, J. IDA Desalination Yearbook 2015-2016; Media Analytics Ltd.: Oxford, UK, 2016.

27. Global Water Intelligence (GWI). Market Profile and Desalination Markets, 2009-2012 Year Books and GWI Website; Global Water Intelligence: Oxford, UK, 2013.

28. Ferroukhi, R.; Nagpal, D.; Lopez-Peña, A.; Hodges, T.; Rabi, H.; Mohtar; Daher, B.; Mohtar, S.; Keulertz, M. Renewable Energy in the Water, Energy \& Food Nexus. International Renewable Energy Agency (IRENA): Abu Dhabi, UAE, 2015. Available online: http:/ / www.irena.org/documentdownloads/publications/irena_ water_energy_food_nexus_2015.pdf (accessed on 20 March 2018).

29. Pugsley, A.; Zacharopoulos, A.; Mondol, J.D.; Smyth, M. Global applicability of solar desalination. Renew. Energy 2016, 88, 200-219. [CrossRef]

30. IEA-ETSAP (International Energy Agency-Energy Technology Systems Analysis Programme) and IRENA (International Renewable Energy Agency). Water Desalination Using Renewable Energy: Technology Brief. 2012. Available online: http:/ / www.irena.org/DocumentDownloads/Publications/Water_Desalination_ Using_Renewable_Energy_-_Technology_Brief.pdf (accessed on 22 March 2018).

31. GEWater. Creating Sustainability through Water Reuse. 2016. Available online: https://www. suezwatertechnologies.com/index.php/applications/desalination (accessed on 28 December 2018).

32. Pike Research. Research Report, Executive summary: Desalination Technology Markets—Global Demand Drivers, Technology Issues, Competitive Landscape, and Market Forecasts; WIPO Coordination Office: New York, NY, USA, 2010. 
33. Desalination and Water Recycling, Mission 2017: Global Water Security, MIT. Available online: http://12. 000.scripts.mit.edu/mission2017/desalination-and-water-recycling/ (accessed on 25 March 2018).

34. Koleva, M.N.; Polykarpou, E.M.; Liu, S.; Styan, C.A.; Papageorgiou, L.G. Optimal design of water treatment processes. Desalin. Water Treat. 2016, 57, 26954-26975. [CrossRef]

35. IEA. World Energy Outlook 2018; International Energy Agency: Paris, France, 2018.

36. GEWater. Wastewater: A Valuable Resource. 2016. Available online: https://www.suezwatertechnologies. com/index.php/applications/desalination (accessed on 28 December 2018).

37. Lee, J.; Choi, J.Y.; Choi, J.-S.; Chu, K.H.; Yoon, Y.; Kim, S. A statistics-based forward osmosis membrane characterization method without pressurized reverse osmosis experiment. Desalination 2017, 403, 36-45. [CrossRef]

38. Manju, S.; Sagar, N. Renewable energy integrated desalination: A sustainable solution to overcome future fresh-water scarcity in India. Renew. Sustain. Energy Rev. 2017, 73, 594-609. [CrossRef]

39. World Health Organization. Safe Drinking-water from Desalination. 2012. Available online: http:/ /apps. who.int/iris/bitstream/10665/70621/1/WHO_HSE_WSH_11.03_eng.pdf (accessed on 6 April 2018).

40. Desalination Technologies and the Use of Alternative Energies for Desalination. 2011. Available online: http:/ / www.wipo.int/export/sites/www / patentscope/en/programs/patent_landscapes/documents / patent_landscapes/948-2E-WEB.pdf (accessed on 5 April 2018).

41. Australia: Water Resources Management. 2012. Available online: http://www.ozh2o.com/h2use4.html (accessed on 15 April 2018).

42. Wheeler, S.A.; MacDonald, D.H.; Boxall, P. Water policy debate in Australia: Understanding the tenets of stakeholders' social trust. Land Use Policy 2017, 63, 246-254. [CrossRef]

43. Ding, G.K.C.; Ghosh, S. Sustainable water management-A strategy for maintaining future water resources. In Reference Module in Earth Systems and Environmental Sciences; Elsevier: Amsterdam, The Netherlands, 2017.

44. Kotir, J.H.; Brown, G.; Marshall, N.; Johnstone, R. Systemic feedback modelling for sustainable water resources management and agricultural development: An application of participatory modelling approach in the Volta River Basin. Environ. Model. Softw. 2017, 88, 106-118. [CrossRef]

45. Wei, J.; Wei, Y.; Western, A. Evolution of the societal value of water resources for economic development versus environmental sustainability in Australia from 1843 to 2011. Glob. Environ. Chang. 2017, 42, 82-92. [CrossRef]

46. Quteishat, K.; Abu-Arabi, M. Promotion of Solar Desalination in the MENA Region. Available online: http:/ / www.sswm.info/sites/default/files/reference_attachments/QUTEISHAT\%20and\%20ABUARABI\%202004\%20Promotion\%20of\%20Solar\%20Desalination\%20in\%20the\%20MENA\%20Region.pdf (accessed on 17 April 2018).

47. Trieb, F.; Müller-Steinhagen, H. Concentrating solar power for seawater desalination in the Middle East and North Africa. Desalination 2008, 220, 165-183. [CrossRef]

48. Shevah, Y. Chapter six-Challenges and solutions to water problems in the Middle East A2-Ahuja, Satinder. In Chemistry and Water; Elsevier: Amsterdam, The Netherlands, 2017.

49. Casey, T. World's Largest Solar Powered, Jellyfish-Fightin' Desalination Plant to Be Built in Saudi Arabia. 2015. Available online: http:/ / cleantechnica.com/2015/01/22/worlds-largest-solar-powered-desalinationplant-under-way/ (accessed on 28 April 2018).

50. Hischier, I.; Hofer, J.; Gunz, L.; Nordborg, H.; Schlüter, A. Ultra-thin and lightweight photovoltaic/thermal collectors for building integration. Energy Procedia 2017, 122, 409-414. [CrossRef]

51. Riffat, S.B.; Cuce, E. A review On Hybrid Photovoltaic/Thermal Collectors and Systems. Int. J. Low-Carbon Technol. 2011, 6, 212-241. [CrossRef]

52. Chu, Y. Review and Comparison of Different Solar Energy Technologies; Global Energy Network Institute (GENI): San Diego, CA, USA, 2011; p. 52.

53. Albloushi, A.; Giwa, A.; Mukherjee, D.; Calabro, V.; Cassano, A.; Chakraborty, S.; Hasan, S.W. Chapter 7-Renewable Energy-Powered Membrane Systems for Water Desalination. In Current Trends and Future Developments on (Bio-) Membranes; Basile, A., Cassano, A., Figoli, A., Eds.; Elsevier, 2019; pp. 153-177.

54. Bozkurt, I.; Karakilcik, M.; Dincer, I. Water desalination technologies utilizing conventional and renewable energy sources. Int. J. Low Carbon Technol. 2014, 9, 1-19. 
55. B2B Connect UAE for Reed Exhibitions. Meeting the GCC's water needs in an environmentally sustainable way. In Proceedings of the International Water Summit in Energy Efficient Desalination, Abu Dhabi, UAE, 15-18 January 2018; pp. 1-16.

56. Hamed, O.A.; Kosaka, H.; Bamardouf, K.H.; Al-Shail, K.; Al-Ghamdi, A.S. Concentrating solar power for seawater thermal desalination. Desalination 2016, 396, 70-78. [CrossRef]

57. Bandi, C.S.; Uppaluri, R.; Kumar, A. Global optimization of MSF seawater desalination processes. Desalination 2016, 394, 30-43. [CrossRef]

58. Moustafa, S.M.A.; Jarrar, D.I.; El-Mansy, H.I. Performance of a self-regulating solar multistage flash desalination system. Sol. Energy 1985, 35, 333-340. [CrossRef]

59. Ullah, I.; Rasul, M.G.; Khan, M.M.K. An overveiw of solar thermal desalination technologies. In Proceedings of the 7th WSEAS International Conference on Renewable Energy Sources (RES'13), Kuala Lumpur, Malaysia, 2-4 April 2013.

60. Ali, M.T.; Fath, H.E.S.; Armstrong, P.R. A comprehensive techno-economical review of indirect solar desalination. Renew. Sustain. Energy Rev. 2011, 15, 4187-4199. [CrossRef]

61. National Research Council. Review of the Desalination and Water Purification Technology Roadmap; National Academies Press: Washington, DC, USA, 2004.

62. Van der Bruggen, B. Desalination by distillation and by reverse osmosis-Trends towards the future. Membr. Technol. 2003, 2003, 6-9. [CrossRef]

63. Azhar, M.S.; Rizvi, G.; Dincer, I. Integration of renewable energy based multigeneration system with desalination. Desalination 2017, 404, 72-78. [CrossRef]

64. García-Rodríguez, L.; Gómez-Camacho, C. Conditions for economical benefits of the use of solar energy in multi-stage flash distillation. Desalination 1999, 125, 133-138. [CrossRef]

65. Mokhtar, M.; Ali, M.T.; Bräuniger, S.; Afshari, A.; Sgouridis, S.; Armstrong, P.; Chiesa, M. Systematic comprehensive techno-economic assessment of solar cooling technologies using location-specific climate data. Appl. Energy 2010, 87, 3766-3778. [CrossRef]

66. Al-Hamahmy, M.; Fath, H.E.S.; Khanafer, K. Techno-economical simulation and study of a novel MSF desalination process. Desalination 2016, 386, 1-12. [CrossRef]

67. Chandrashekara, M.; Yadav, A. Water desalination system using solar heat: A review. Renew. Sustain. Energy Rev. 2017, 67, 1308-1330.

68. Zhang, L.-Z.; Li, G.-P. Energy and economic analysis of a hollow fiber membrane-based desalination system driven by solar energy. Desalination 2017, 404, 200-214. [CrossRef]

69. Bataineh, K.M. Multi-effect desalination plant combined with thermal compressor driven by steam generated by solar energy. Desalination 2016, 385, 39-52. [CrossRef]

70. Darwish, M.A.; Abdulrahim, H.K. Feed water arrangements in a multi-effect desalting system. Desalination 2008, 228, 30-54. [CrossRef]

71. Pouyfaucon, A.B.; García-Rodríguez, L. Solar thermal-powered desalination: A viable solution for a potential market. Desalination 2018, 435, 60-69. [CrossRef]

72. Sharaf, M.A.; Nafey, A.S.; García-Rodríguez, L. Exergy and thermo-economic analyses of a combined solar organic cycle with multi effect distillation (MED) desalination process. Desalination 2011, 272, 135-147. [CrossRef]

73. Buros, O.K. The ABCs of Desalting; International Desalination Association: Topsfield, MA, USA, 2000.

74. United Nations. Economic and Social Commission for Western Asia. Water Desalination Technologies in the ESCWA Member Countries, Economic and Social Commission for Western Asia; United Nations: New York, NY, USA, 2001.

75. Darwish, M.A.; El-Dessouky, H. The heat recovery thermal vapour-compression desalting system: A comparison with other thermal desalination processes. Appl. Therm. Eng. 1996, 16, 523-537. [CrossRef]

76. Clayton, R. Desalination for Water Supply: A Review of Current Knowledge; Foundation for Water Research: Buckinghamshire, UK, 2015.

77. Wang, Q.; Li, N.; Bolto, B.; Hoang, M.; Xie, Z. Desalination by pervaporation: A review. Desalination 2016, 387, 46-60. [CrossRef]

78. Jones, M.A.; Odeh, I.; Haddad, M.; Mohammad, A.H.; Quinn, J.C. Economic analysis of photovoltaic (PV) powered water pumping and desalination without energy storage for agriculture. Desalination 2016, 387, 35-45. [CrossRef] 
79. Stambouli, A.B.; Khiat, Z.; Flazi, S.; Tanemoto, H.; Nakajima, M.; Isoda, H.; Yokoyama, F.; Hannachi, S.; Kurokawa, K.; Shimizu, M.; et al. Trends and challenges of sustainable energy and water research in North Africa: Sahara solar breeder concerns at the intersection of energy/water. Renew. Sustain. Energy Rev. 2014, 30, 912-922. [CrossRef]

80. Tiwari, G.N.; Sahota, L. Review on the energy and economic efficiencies of passive and active solar distillation systems. Desalination 2017, 401, 151-179. [CrossRef]

81. Ibrahimi, M.; Arbaoui, A.; Aoura, Y. Design analysis of MVC desalination unit powered by a grid connected photovoltaic system. Energy Procedia 2017, 139, 524-529. [CrossRef]

82. Shalaby, S.M. Reverse osmosis desalination powered by photovoltaic and solar Rankine cycle power systems: A review. Renew. Sustain. Energy Rev. 2017, 73, 789-797. [CrossRef]

83. Khawaji, A.D.; Kutubkhanah, I.K.; Wie, J.-M. A 13.3 MGD seawater RO desalination plant for Yanbu Industrial City. Desalination 2007, 203, 176-188. [CrossRef]

84. Alsheghri, A.; Sharief, S.A.; Rabbani, S.; Aitzhan, N.Z. Design and cost analysis of a solar photovoltaic powered reverse osmosis plant for Masdar institute. Energy Procedia 2015, 75, 319-324. [CrossRef]

85. Alajlan, S.A.; Smiai, M.S. Performance and development of PV-plant for water pumping and desalination for remote area in Saudi Arabia. Renew. Energy 1996, 8, 441-446. [CrossRef]

86. Shen, J.; Richards, B.S.; Schäfer, A.I. Renewable energy powered membrane technology: Case study of St. Dorcas borehole in Tanzania demonstrating fluoride removal via nanofiltration/reverse osmosis. Sep. Purif. Technol. 2016, 170, 445-452. [CrossRef]

87. Kosmadakis, G.; Manolakos, D.; Kyritsis, S.; Papadakis, G. Design of a two stage Organic Rankine Cycle system for reverse osmosis desalination supplied from a steady thermal source. Desalination 2010, 250, 323-328. [CrossRef]

88. Nafey, A.S.; Sharaf, M.A.; García-Rodríguez, L. Thermo-economic analysis of a combined solar organic Rankine cycle-reverse osmosis desalination process with different energy recovery configurations. Desalination 2010, 261, 138-147. [CrossRef]

89. Salcedo, R.; Antipova, E.; Boer, D.; Jiménez, L.; Guillén-Gosálbez, G. Multi-objective optimization of solar Rankine cycles coupled with reverse osmosis desalination considering economic and life cycle environmental concerns. Desalination 2012, 286, 358-371. [CrossRef]

90. Laborde, H.M.; França, K.B.; Neff, H.; Lima, A.M.N. Optimization strategy for a small-scale reverse osmosis water desalination system based on solar energy. Desalination 2001, 133, 1-12. [CrossRef]

91. Sajjad, M.; Rasul, M.G. Simulation and optimization of solar desalination plant using Aspen Plus simulation software. Procedia Eng. 2015, 105, 739-750. [CrossRef]

92. Li, C.; Goswami, Y.; Stefanakos, E. Solar assisted sea water desalination: A review. Renew. Sustain. Energy Rev. 2013, 19, 136-163. [CrossRef]

93. Lin, S.; Elimelech, M. Staged reverse osmosis operation: Configurations, energy, efficiency, and application potential. Desalination 2015, 366, 9-14. [CrossRef]

94. Khawaji, A.D.; Kutubkhanah, I.K.; Wie, J.-M. Advances in seawater desalination technologies. Desalination 2008, 221, 47-69. [CrossRef]

95. Onsekizoglu, P. Membrane distillation: Principle, advances, limitations and future prospects in food industry. In Distillation-Advances from Modeling to Applications; Intech Open: London, UK, 2012.

96. Fernandez-Gonzalez, C.; Dominguez-Ramos, A.; Ibañez, R.; Irabien, A. Sustainability assessment of electrodialysis powered by photovoltaic solar energy for freshwater production. Renew. Sustain. Energy Rev. 2015, 47, 604-615. [CrossRef]

97. Elzahaby, A.M.; Kabeel, A.E.; Bassuoni, M.M.; Elbar, A.R.A. Direct contact membrane water distillation assisted with solar energy. Energy Convers. Manag. 2016, 110, 397-406. [CrossRef]

98. Yang, X.; Fane, A.G.; Wang, R. Membrane distillation: Now and future. In Desalination: Water from Water; Kucera, J., Ed.; Wiley: Hoboken, NY, USA, 2014.

99. Guan, G.; Yang, X.; Wang, R.; Fane, A.G. Evaluation of heat utilization in membrane distillation desalination system integrated with heat recovery. Desalination 2015, 366, 80-93. [CrossRef]

100. Al-Obaidani, S.; Curcio, E.; Macedonio, F.; Profio, G.D.; Al-Hinai, H.; Drioli, E. Potential of membrane distillation in seawater desalination: Thermal efficiency, sensitivity study and cost estimation. J. Membr. Sci. 2008, 323, 85-98. [CrossRef] 
101. Alklaibi, A.M.; Lior, N. Membrane-distillation desalination: Status and potential. Desalination 2005, 171, 111-131. [CrossRef]

102. Suárez, F.; Ruskowitz, J.A.; Tyler, S.W.; Childress, A.E. Renewable water: Direct contact membrane distillation coupled with solar ponds. Appl. Energy 2015, 158, 532-539. [CrossRef]

103. Rozanska, A.; Wisniewski, J. Brackish water desalination with the combination of Donnan dialysis and electrodialysis. Desalination 2006, 200, 615-617. [CrossRef]

104. Younos, T.; Tulou, K.E. Overview of Desalination Tecqniques. J. Contemp. Water Res. Educ. 2005, 132, 3-10. [CrossRef]

105. Xu, Z.; Xu, L. Freezing Desalination Process. Therm. Desalin. Process. 2010, 2, 1-7.

106. Rahman, M.S.; Ahmed, M.; Chen, X.D. Freezing-Melting process and desalination: I. review of the state-of-the-art. Sep. Purif. Rev. 2006, 35, 59-96. [CrossRef]

107. Chang, J.; Zuo, J.; Lu, K.-J.; Chung, T.-S. Freeze desalination of seawater using LNG cold energy. Water Res. 2016, 102, 282-293. [CrossRef]

108. Lu, H.; Wang, J.; Wang, T.; Wang, N.; Bao, Y.; Hao, H. Crystallization techniques in wastewater treatment: An overview of applications. Chemosphere 2017, 173, 474-484. [CrossRef]

109. Kucera, J. Introduction to Desalination. In Desalination; Scrivener Publishing LLC.: Beverly, MA, USA, 2014. [CrossRef]

110. El Kadi, K.; Janajreh, I. Desalination by Freeze Crystallization: An Overview. Int. J. Therm. Environ. Eng. 2017, 15, 103-110.

111. Mahdavi, M.; Mahvi, A.H.; Nasseri, S.; Yunesian, M. Application of Freezing to the Desalination of Saline Water. Arab. J. Sci. Eng. 2011, 36, 1171-1177. [CrossRef]

112. Tanaka, Y. Ion-exchange membrane electrodialysis program and its application to multi-stage continuous saline water desalination. Desalination 2012, 301, 10-25. [CrossRef]

113. Shahabi, M.P.; McHugh, A.; Anda, M.; Ho, G. Comparative economic and environmental assessments of centralised and decentralised seawater desalination options. Desalination 2015, 376, 25-34. [CrossRef]

114. Lior, N. Sustainability as the quantitative norm for water desalination impacts. Desalination 2017, 401, 99-111. [CrossRef]

115. Enríquez-de-Salamanca, Á.; Díaz-Sierra, R.; Martín-Aranda, R.M.; Santos, M.J. Environmental impacts of climate change adaptation. Environ. Impact Assess. Rev. 2017, 64, 87-96. [CrossRef]

116. Lattemann, S. Potential Impacts of Seawater Desalination. Available online: http://www.paua.de/Impacts. htm (accessed on 28 August 2018).

117. Höpner, T.; Lattemann, S. Environmental impact and impact assessment of seawater desalination. Desalination 2008, 220, 1-15.

118. Hoepner, T.; Lattemann, S. Chemical impacts from seawater desalination plants-A case study of the northern Red Sea. Desalination 2003, 152, 133-140. [CrossRef]

119. Cherchi, C.; Badruzzaman, M.; Becker, L.; Jacangelo, J.G. Natural gas and grid electricity for seawater desalination: An economic and environmental life-cycle comparison. Desalination 2017, 414, 89-97. [CrossRef]

120. Balfaqih, H.; Al-Nory, M.T.; Nopiah, Z.M.; Saibani, N. Environmental and economic performance assessment of desalination supply chain. Desalination 2017, 406, 2-9. [CrossRef]

121. Cherif, H.; Champenois, G.; Belhadj, J. Environmental life cycle analysis of a water pumping and desalination process powered by intermittent renewable energy sources. Renew. Sustain. Energy Rev. 2016, 59, 1504-1513. [CrossRef]

122. Fuentes-Bargues, J.L. Analysis of the process of environmental impact assessment for seawater desalination plants in Spain. Desalination 2014, 347, 166-174. [CrossRef]

123. Dawoud, M.A. Environmental Impacts of Seawater Desalination: Arabian Gulf Case Study. Int. J. Environ. Sustain. 2012, 1, 22-37. [CrossRef]

124. Darwish, M.; Hassabou, A.H.; Shomar, B. Using Seawater Reverse Osmosis (SWRO) desalting system for less environmental impacts in Qatar. Desalination 2013, 309, 113-124. [CrossRef]

125. World Health Organization. Desalination for Safe Water Supply: Guidance for the Health and Environmental Aspects Applicable to Desalination; World Health Organization: Geneva, Switzerland, 2007.

126. Liu, T.-K.; Sheu, H.-Y.; Tseng, C.-N. Environmental impact assessment of seawater desalination plant under the framework of integrated coastal management. Desalination 2013, 326, 10-18. [CrossRef] 
127. Peters, T.; Pintó, D. Seawater intake and pre-treatment/brine discharge-Environmental issues. Desalination 2008, 221, 576-584. [CrossRef]

128. The Australian Institute of Refrigeration, Air Conditioning and Heating. Methods of Calculating Total Equivalent Warming Impact (TEWI); AIRAH: Melbourne, Australia, 2012.

129. United States Environmental Protection Agency (EPA). Global Greenhouse Gas Emissions Data. Available online: https://www.epa.gov/ghgemissions/global-greenhouse-gas-emissions-data (accessed on 11 November 2018).

130. Missimer, T.M.; Jones, B.; Maliva, R.G. Intakes and Outfalls for Seawater Reverse Osmosis Desalination Facilities: Innovations and Environmental Impacts; Springer International Publishing: Basel, Switzerland, 2015.

131. Missimer, T.M.; Maliva, R.G. Environmental issues in seawater reverse osmosis desalination: Intakes and outfalls. Desalination 2018, 434, 198-215. [CrossRef]

132. Nagappan, P. How Desalination Plants Are Trying to Overcome Environmental Concerns. 2017. Available online: https:/ / www.newsdeeply.com/water/articles/2017/03/03/how-desalination-plants-are-tryingto-overcome-environmental-concerns (accessed on 15 August 2018).

133. Tong, T.; Elimelech, M. The Global Rise of Zero Liquid Discharge for Wastewater Management: Drivers, Technologies, and Future Directions. Environ. Sci. Technol. 2016, 50, 6846-6855. [CrossRef] [PubMed]

134. Jeppesen, T.; Shu, L.; Keir, G.; Jegatheesan, V. Metal recovery from reverse osmosis concentrate. J. Clean. Prod. 2009, 17, 703-707. [CrossRef]

135. Bienskowski, B. Desalination is an Expensive Energy Hog, but Improvements are on the Way. 2015. Available online: https:/ / www.pri.org/stories /2015-05-15/desalination-expensive-energy-hog-improvements-areway (accessed on 20 August 2018).

136. Ortega-Delgado, B.; García-Rodríguez, L.; Alarcón-Padilla, D.-C. Thermoeconomic comparison of integrating seawater desalination processes in a concentrating solar power plant of 5 MWe. Desalination 2016, 392, 102-117. [CrossRef]

137. Sharaf Eldean, M.A.; Soliman, A.M. A novel study of using oil refinery plants waste gases for thermal desalination and electric power generation: Energy, exergy \& cost evaluations. Appl. Energy 2017, 195, 453-477.

138. Diaf, A.; Cherfa, A.; Karadaniz, L.; Tigrine, Z. A technical-economical study of solar desalination. Desalination 2016, 377, 123-127. [CrossRef]

139. El-Bialy, E.; Shalaby, S.M.; Kabeel, A.E.; Fathy, A.M. Cost analysis for several solar desalination systems. Desalination 2016, 384, 12-30. [CrossRef]

140. Guillén-Burrieza, E.; Alarcón-Padilla, D.-C.; Palenzuela, P.; Zaragoza, G. Techno-economic assessment of a pilot-scale plant for solar desalination based on existing plate and frame MD technology. Desalination 2015, $374,70-80$.

141. Khan, S.U.-D.; Ud-DinKhan, S.; Haider, S.; El-Leathy, A.; Rana, U.A.; Danish, S.N.; Ullahf, R. Development and techno-economic analysis of small modular nuclear reactor and desalination system across Middle East and North Africa region. Desalination 2017, 406, 51-59. [CrossRef]

142. Karagiannis, I.C.; Soldatos, P.G. Water desalination cost literature: Review and assessment. Desalination 2008, 223, 448-456. [CrossRef]

143. Alkaisi, A.; Mossad, R.; Sharifian-Barforoush, A. A Review of the Water Desalination Systems Integrated with Renewable Energy. Energy Procedia 2017, 110, 268-274. [CrossRef]

144. The Ashkelon Seawater Reverse Osmosis (SWRO) Plant, Water Technology Net. 2011. Available online: http:/ / www.water-technology.net/projects / Israel (accessed on 1 July 2018).

145. Lattemann, S.; Kennedy, M.D.; Schippers, J.C.; Amy, G. Chapter 2 Global Desalination Situation. Sustain. Sci. Eng. 2010, 2, 7-39.

146. Khoshrou, I.; Jafari Nasr, M.R.; Bakhtari, K. New opportunities in mass and energy consumption of the Multi-Stage Flash Distillation type of brackish water desalination process. Sol. Energy 2017, 153, 115-125. [CrossRef]

147. Liu, C.; Rainwater, K.; Song, L. Energy analysis and efficiency assessment of reverse osmosis desalination process. Desalination 2011, 276, 352-358. [CrossRef]

148. Zotalis, K.; Dialynas, E.G.; Mamassis, N.; Angelakis, A.N. Desalination Technologies: Hellenic Experience. Water 2014, 6, 1134-1150. [CrossRef] 
149. Arani, A.M.A.; Zamani, V.; Behbahaninia, A. Economic analysis of a combined power and desalination plant considering availability changes due to degradation. Desalination 2017, 414, 1-9. [CrossRef]

150. Tsai, Y.-C.; Chiu, C.-P.; Ko, F.-K.; Chen, T.-C.; Yang, J.-T. Desalination plants and renewables combined to solve power and water issues. Energy 2016, 113, 1018-1030. [CrossRef]

151. Di Gianfrancesco, A. The Fossil Fuel Power Plants Technology, in Materials for Ultra-Supercritical and Advanced Ultra-Supercritical Power Plants; Woodhead Publishing: Cambridge, UK, 2017; pp. 1-49.

152. Lamei, A.; van der Zaag, P.; von Münch, E. Impact of solar energy cost on water production cost of seawater desalination plants in Egypt. Energy Policy 2008, 36, 1748-1756. [CrossRef]

153. Gu, Y.; Li, Y.; Li, X.; Luo, P.; Wang, H.; Robinson, Z.P.; Wang, X.; Wu, J. The feasibility and challenges of energy self-sufficient wastewater treatment plants. Appl. Energy 2014, 1463-1475. [CrossRef]

C 2018 by the authors. Licensee MDPI, Basel, Switzerland. This article is an open access article distributed under the terms and conditions of the Creative Commons Attribution (CC BY) license (http:// creativecommons.org/licenses/by/4.0/). 